\title{
Learning \\ from Leaders
}

Nordic and International

Best Practice with Fossil

Fuel Subsidy Reform

(1) Nordic Council of Ministers 


\section{Learning from Leaders}

Nordic and International Best Practice with Fossil Fuel Subsidy Reform

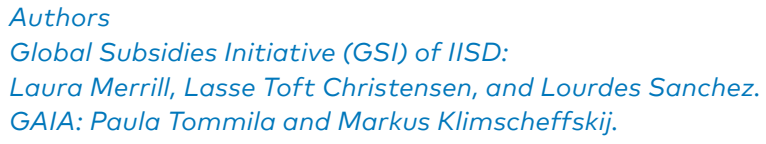

(c) Nordic Council of Ministers 2016

Design: Kontrapunkt

All photos: unsplash.com

Print: Rosendahls

Copies: 200

Printed in Denmark

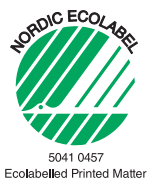

This publication has been published with financial support by the Nordic Council of Ministers. However, the contents of this publication do not necessarily reflect the views, policies or recommendations of the Nordic Council of Ministers. www.norden.org/nordpub

\section{Nordic Co-operation}

Nordic co-operation is one of the world's most extensive forms of regional collabo-ration, involving Denmark, Finland, Iceland, Norway, Sweden, and the Faroe Islands, Greenland, and Åland. Nordic co-operation has firm traditions in politics, the economy, and culture. It plays an important role in European and international collaboration, and aims at creating a strong Nordic community in a strong Europe. Nordic co-operation seeks to safeguard Nordic and regional interests and principles in the global community. Common Nordic values help the region solidify its position as one of the world's most innovative and competitive.

\section{Nordic Council of Ministers}

Ved Stranden 18

DK-1061 Copenhagen $\mathrm{K}$

www.norden.org 
<smiles>[Te]</smiles> 



\section{If we aim to reduce global emissions in order to limit global warming to less than $2^{\circ} \mathrm{C}$ above pre-industrial levels, then the energy sector is of paramount importance.}

A critical change will be national fuel switching away from carbon-intensive sources and increased effort towards energy efficiency and sustainable energy. Subsidies and support from governments to fossil fuels encourage the opposite.

Many countries and regions are making this switch: from subsidising fossil fuels and towards investing in sustainable energy. This brochure describes how Ethiopia, Morocco, Peru and the Philippines have reformed their subsidies. It also describes how countries including Denmark, Finland, Norway and Sweden have introduced innovative policy instruments to encourage switching towards renewable and sustainable energy. 


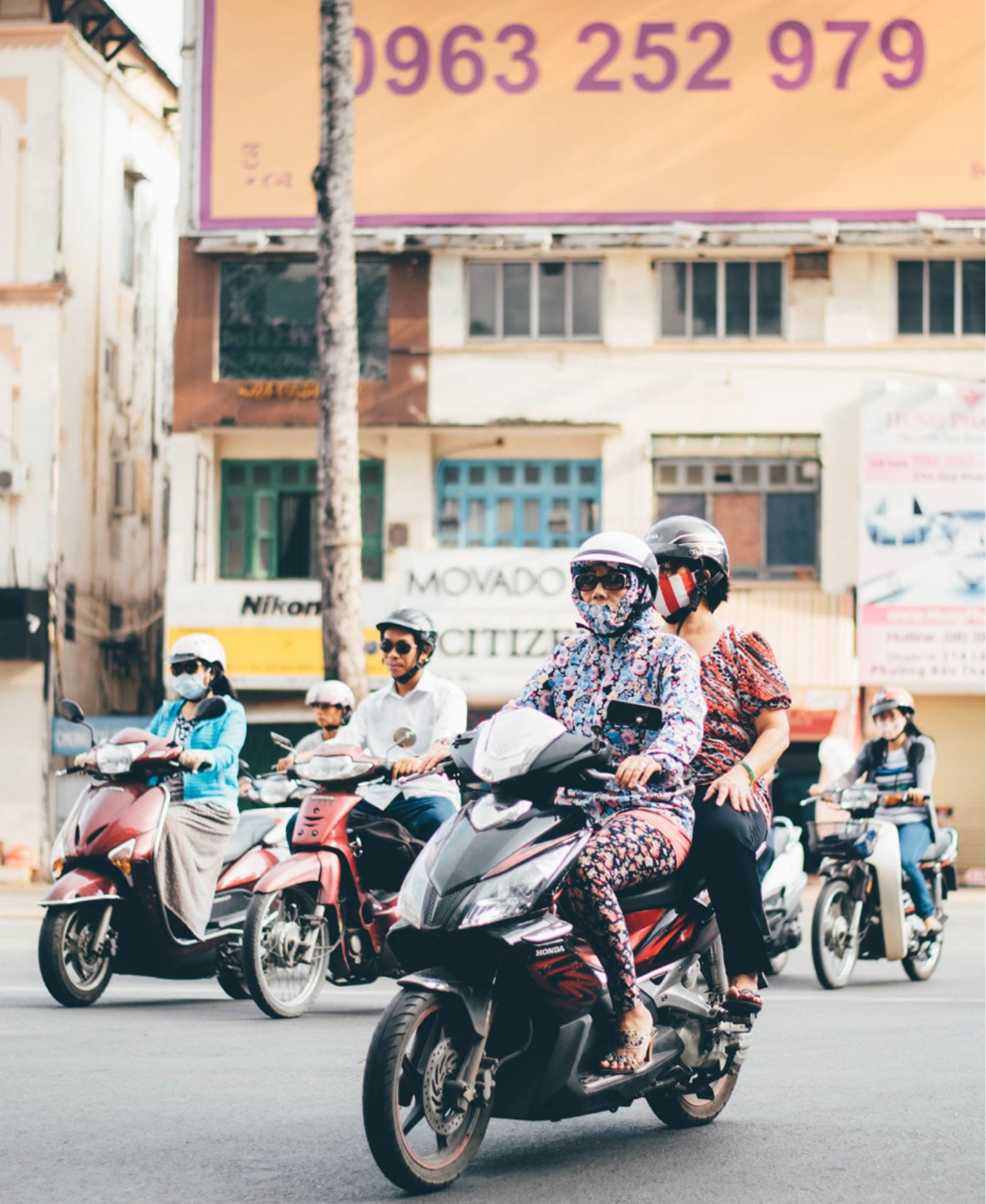




\section{Contents}

Chapter 1

Fossil Fuel Subsidies and the Energy Transition

Chapter 2

Fossil Fuel Subsidies and Climate Change

Chapter 3

Opportunities for Domestic Resources and Revenue

Chapter 4

Opportunities for Early Action

Chapter 5

Morocco

Chapter 6

The Philippines

Chapter 7

Ethiopia

Chapter 8

Peru

Chapter 9

Nordics

Chapter 10

Nordic Leadership and Support on FFSR 
15.er

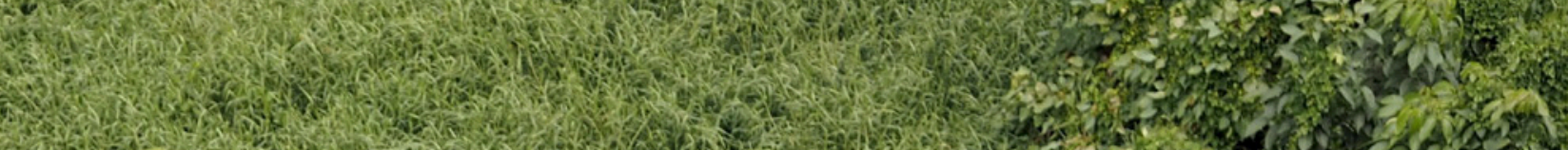

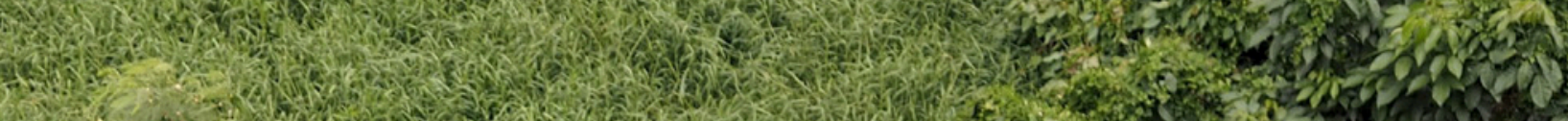
s.535.

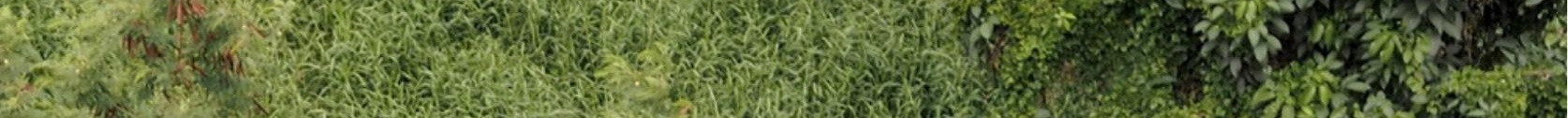
Af

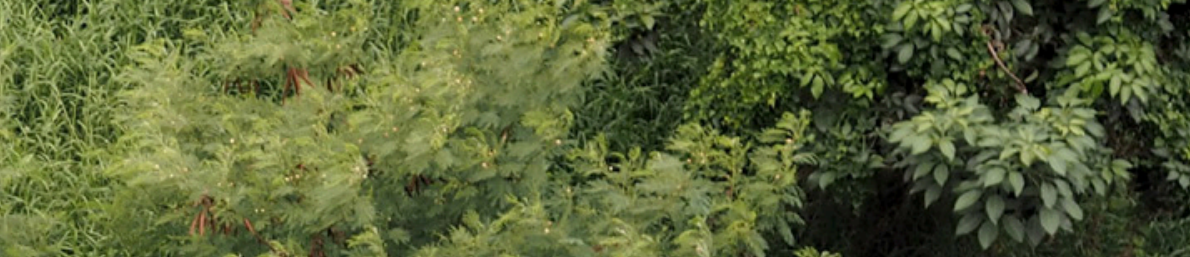

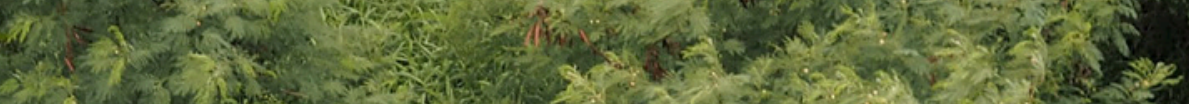

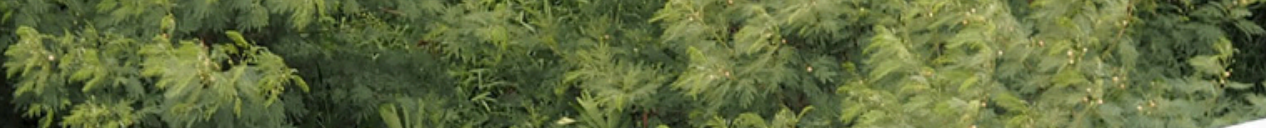

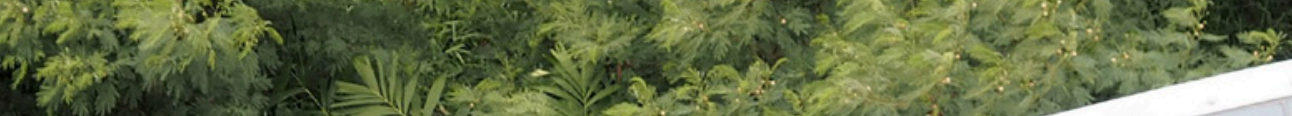

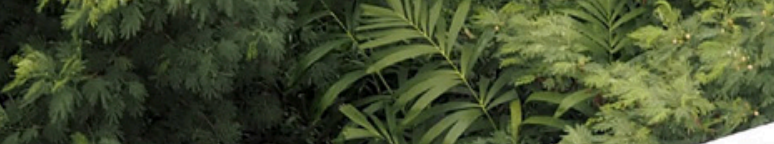

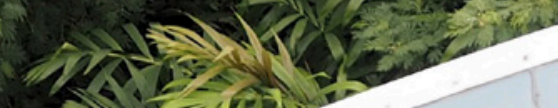

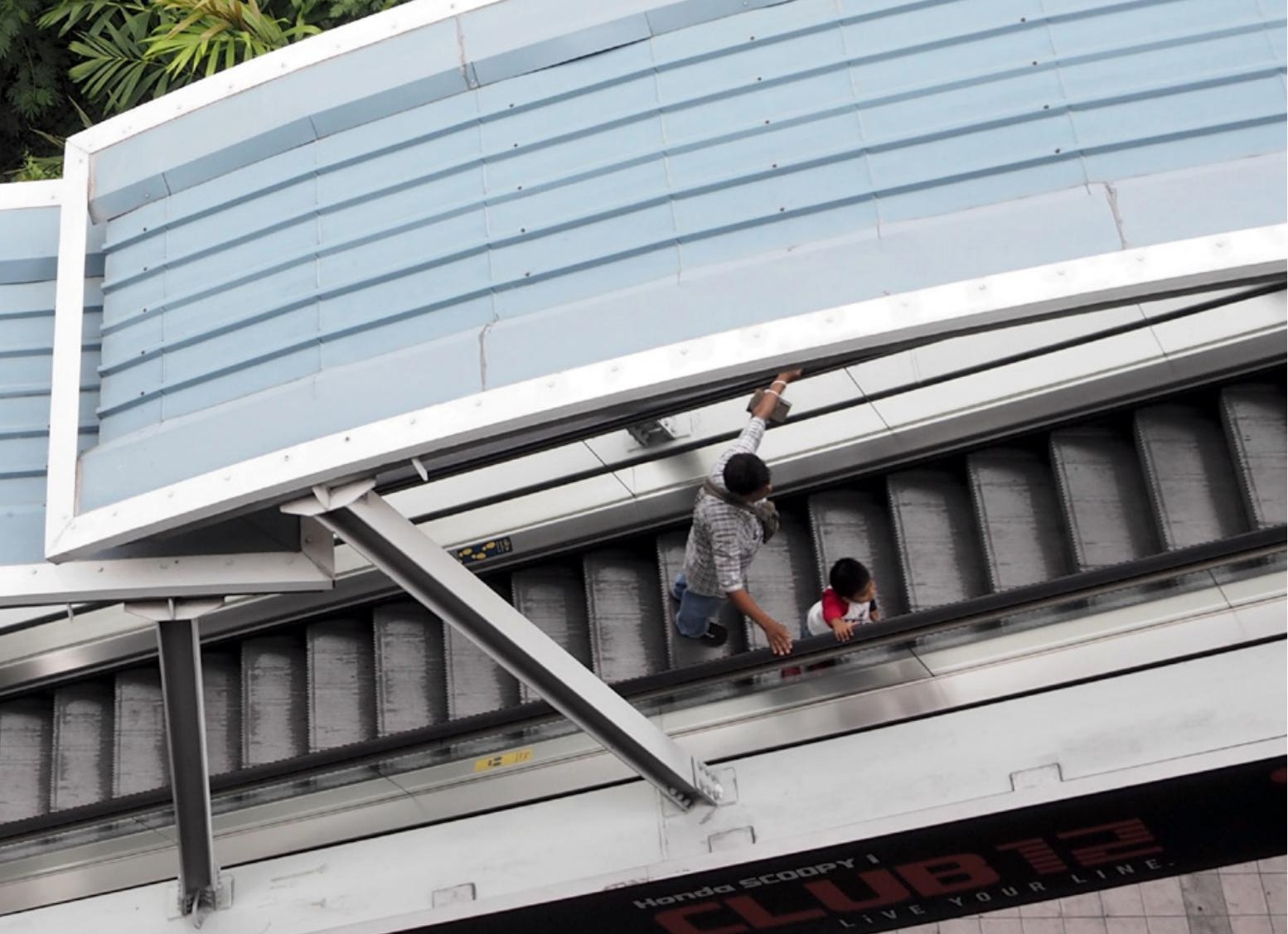




\section{Chapter 1}

\section{Fossil Fuel Subsidies and the Energy Transition}

If we aim to reduce global emissions in order to limit global warming to less than $2^{\circ} \mathrm{C}$ above preindustrial levels, then the energy sector is of paramount importance. A critical change will be national fuel switching away from carbon-intensive sources and efforts towards increasing energy efficiency. Subsidies and support from government to fossil fuels encourage the opposite. Governments the world over continue to subsidise fossil fuels linked to harmful climate change. Globally subsidies amount to around USD 500 billion annually to consumers (IEA,2015a).

Such subsidies are equivalent to around four times the level of subsidies currently directed at renewables and four times the level of private investment into energy efficiency. Fossil fuel subsidies also equate to five times the amount the world has promised to raise annually toward low-emission and climate-resilient development pathways by 2020 (USD 100 billion annual target). Such subsidies to fossil fuels also represent around half of the budget needed to fund the clean energy transition: i.e. to achieve universal energy access, double the share of renewable energy in the global energy mix and double the rate of improvement in energy efficiency by 2030 (estimated to cost USD 1 trillion annually).

Many countries and regions, as described in this brochure, are making this switch: away from subsidising fossil fuels and towards investing in sustainable energy. At least 14 countries included fossil fuel and energy sector reform as one policy instrument to help support climate goals within their Intended Nationally Determined Contributions (INDCs) (Terton et al., 2015). In 2014 almost 30 countries, including Egypt, Indonesia and India, delivered some form of fossil fuel subsidy reform (FFSR). 
The countries described in this brochure (Denmark, Ethiopia, Finland, Morocco, Peru, Philippines, Sweden and Norway) have also come together with over 40 countries and representatives of over 15,000 businesses to endorse an international Communiqué on Fossil Fuel Subsidy Reform (www.fffsr.org).

Some, like Peru, have led in a process of peer review of national subsidies, which others like the United States and China have followed. Many more countries could also take this opportunity to make the switch from fossil fuel subsidies to sustainable energy, following the examples set by these leaders. 


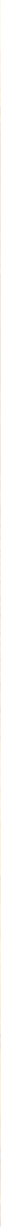




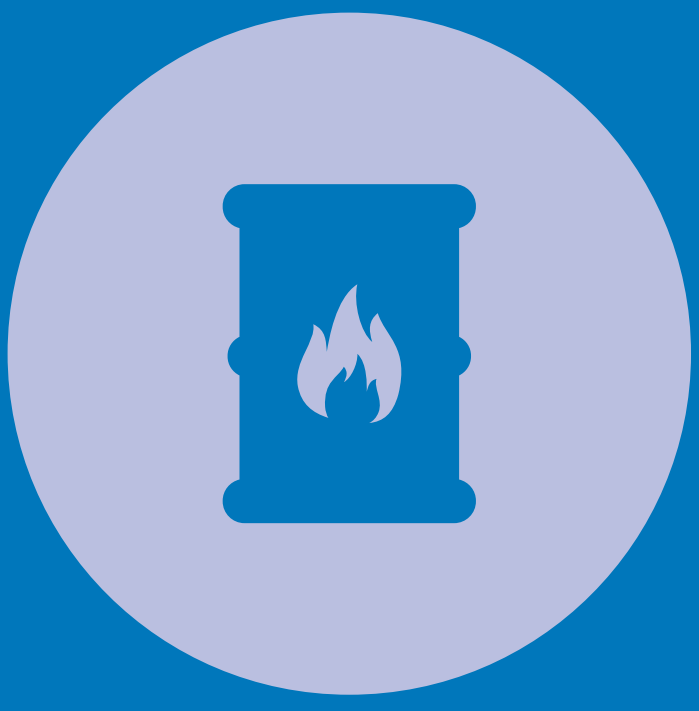

Fossil fuel subsidies

$\$ 493$ B

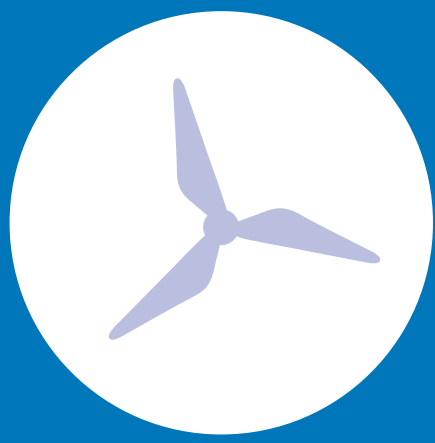

Renewable energy $\$ 135$ B

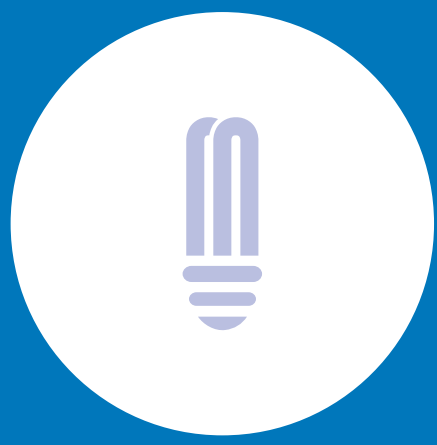

Energy effieciency

$\$ 120$ B

Fossil fuel subsidies stood at $\$ 493$ billion dollars in 2014 (IEA, 2015a). This is almost four times the value of subsidies to renewable energy. It is also more than four times the amount of private finance invested globally in improving energy efficiency in 2013 (IEA, 2014). 


\section{Chapter 2}

\section{Fossil Fuel Subsidies and Climate Change}

As well as the opportunity to free up vital resources to help finance sustainable energy and development, research finds that reform and removal of these subsidies could lead to co-benefits of global emissions reductions of around 3 per cent by 2020, rising to around 8 per cent by 2050. The International Energy Agency (IEA, 2015b) finds a 10 per cent reduction in energy sector emissions by 2030, from accelerating the partial phase-out of subsidies to fossil fuel consumption.

A working paper from the International Monetary Fund (Coady, Parry, Sears, \& Shang, 2015) finds that removing subsidies and then taxing fossil fuels effectively could represent a potential global revenue increase to governments of USD 2.9 trillion and "cut global $\mathrm{CO} 2$ emissions by more than 20 percent, and cut premature air pollution deaths by more than half"p.7. Separate research based on data from the last 30 years of industrial development pathways across 170 countries finds that the financial and environmental costs of such subsidies are enormous. For 2010 alone, the research finds that "the total global direct and indirect financial costs of all such subsidies amounted to $\$ 1.82$ trillion, or $3.8 \%$ of global GDP. Aside from the money saved, in 2010 a world without subsidies would have had carbon emissions $36 \%$ lower than they actually were" (Stefanski, 2016, p.1). It is clear that, as a policy instrument, with impacts on both the economy and the environment, such subsidies matter.

Global data sets are useful to provide the 'big picture,' but targeted country information is also required for governments to understand the impact that such policy changes can have on the economy, society and for emissions reductions. 


\section{$\mathrm{CO} 2$}

\section{emissions}

down

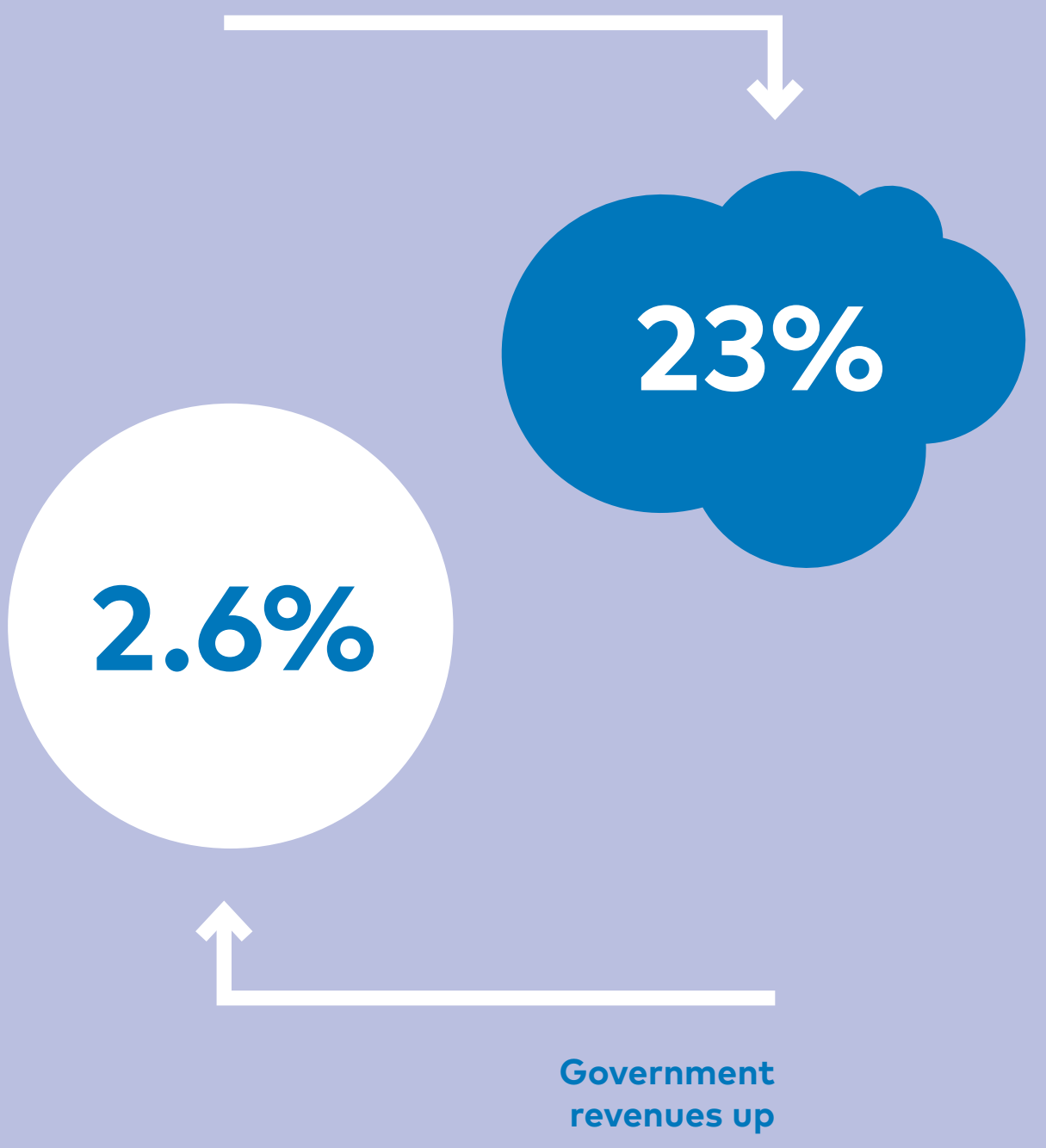

By removing subsidies and taxing carbon correctly, we could reduce global $\mathrm{CO} 2$ emissions by $23 \%$ and raise government revenue through savings and taxation equivalent to $2.6 \%$ of global GDP (Parry et al., 2014). 
Research for the Nordic Council of Ministers (Merrill, Bassi, Bridle, \& Christensen, 2015), and shared with policy-makers prior to the 2015 Paris negotiations, analysed the potential impact of a phased removal of subsidies on national greenhouse gas (GHG) emissions. This policy change was modelled for 20 countries between now and 2020. Cumulative savings from across the 20 countries by 2020 from removal of these subsidies alone amount to $2.8 \mathrm{Gt}$ of $\mathrm{CO} 2 \mathrm{e}$.

The research found a national average of 11 per cent emissions reduction from the removal of fossil fuel subsidies (against BAU) through this pre-2020 action. This reduction in emissions could be improved to 18 per cent if a small share of the savings from subsidy reform (a modest 30 per cent) is made into a parallel reinvestment into energy efficiency and renewables.

Average emissions reductions from FFSR across 20 countries, with $10 \%$ of savings invested in renewables and $20 \%$ into energy efficiency

- Fossil fuel subsidy reform $\square$ Renewable energy

Energy efficiency - Source: (Merrillet et al., 2015)

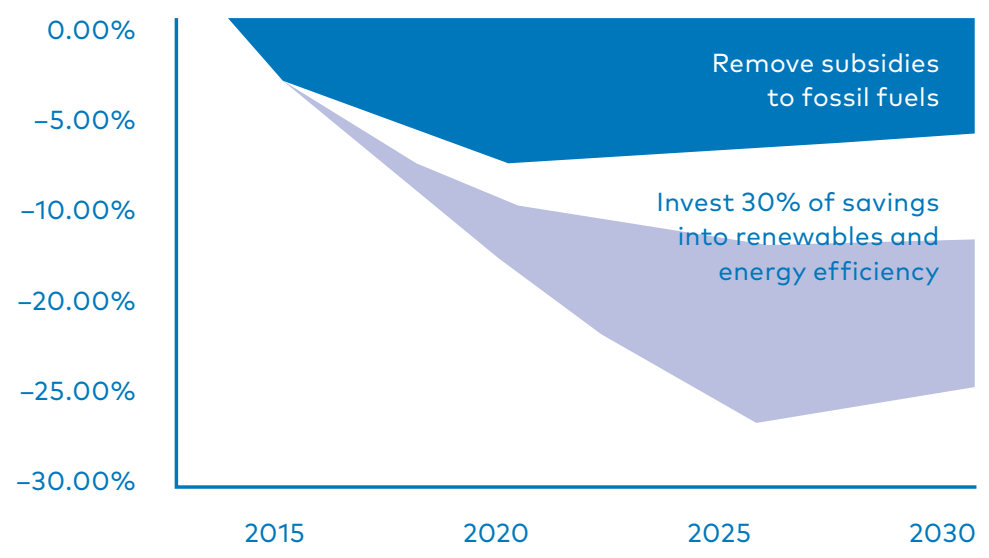




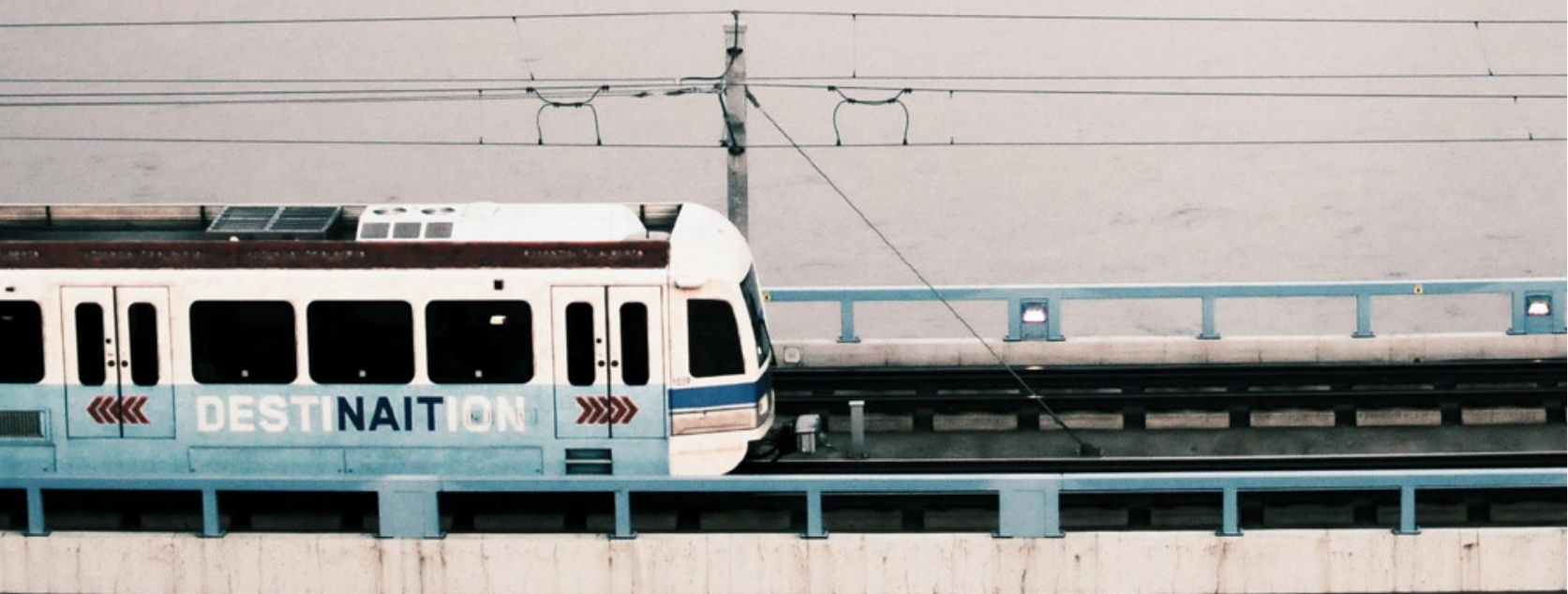




\section{Chapter 3}

\section{Opportunities for Domestic Resources and Revenue}

A key issue for governments from the reform of fossil fuel subsidies is the savings that such reform unlocks for domestic resources and potential for ongoing revenues towards sustainable development. Furthermore, the economic distortion from transport fuel subsidies has been estimated to amount to USD 44 billion of deadweight loss for 2012 across 10 countries with the highest subsidies (Davis, 2014). As a result of such large sums and inefficiency, FFSR was recognised within both the Sustainable Development Goals and Financing for Development agreement in 2015. The potential for this policy change to unlock domestic resources is significant

Real world examples bear these findings out. Many countries are reforming, especially given the recent low oil prices, which make reform easier in that pass-through costs to consumers are lower and in that the scale of the subsides are reduced (especially for importing countries). Nevertheless, the IEA (2015a) finds that active reform efforts of countries are also making a significant impact on the scale of the problem, pointing out that "without the reforms adopted since 2009, the value of fossil-fuel subsidies would have been $24 \%$ higher ( $\$ 117$ billion), putting the level of these subsidies at $\$ 610$ billion in $2014 "$ p.96. For example, Indonesia was able to free up around USD 15.6 billion through a combination of FFSRs (largely removing significant gasoline and diesel subsidies) and falling world oil prices, enabling a major step forward in improving public expenditure in Indonesia (Pradiptyo et al., 2015). Pricing reforms in India, mainly to gasoline (2010) and diesel (2014) have cut the country's subsidies bill in 2014 by USD 15 billion (IEA, 2015a), while subsidy reforms have led to the parallel implementation of the largest cash transfer program in the world. 
Language on FFSR

in international outcomes in 2015

\section{Sustainable Development Goals}

Means of Implementation, within Goal 12: "Ensure sustainable consumption and production patterns"12.c "Rationalize inefficient fossil-fuel subsidies that encourage wasteful consumption by removing market distortions, in accordance with national circumstances, including by restructuring taxation and phasing out those harmful subsidies, where they exist, to reflect their environmental impacts, taking fully into account the specific needs and conditions of developing countries and minimizing the possible adverse impacts on their development in a manner that protects the poor and the affected communities."

\section{Financing for Development: Addis Ababa Action Agenda}

Paragraph 31: "We reaffirm the commitment to rationalize inefficient fossil-fuel subsidies that encourage wasteful consumption by removing market distortions, in accordance with national circumstances, including by restructuring taxation and phasing out those harmful subsidies, where they exist, to reflect their environmental impacts, taking fully into account the specific needs and conditions of developing countries and minimizing the possible adverse impacts on their development in a manner that protects the poor and the affected communities."

\section{UN Framework Convention}

\section{on Climate Change: Paris Agreement}

Although no direct mention of FFSR within the agreement, some countries chose to include the issue within their national contributions. There were 14 specific mentions of 'fossil fuel" or "energy sector reform" as part of national contributions, and 39 mentions of "fiscal measures" in general, representing 67 countries (i.e. removal of fossil fuel subsidies [14 NDCs], implementation of clean energy subsidies [25] and carbon pricing [13]). Within the Paris Agreement, no specific mention but sections on transparency (Article 13), and capacity building (Article 11) hold potential. For example on capacity building: following proposals a Technical Experts Meeting of the UNFCCC, held in June 2016, covered the topic. 


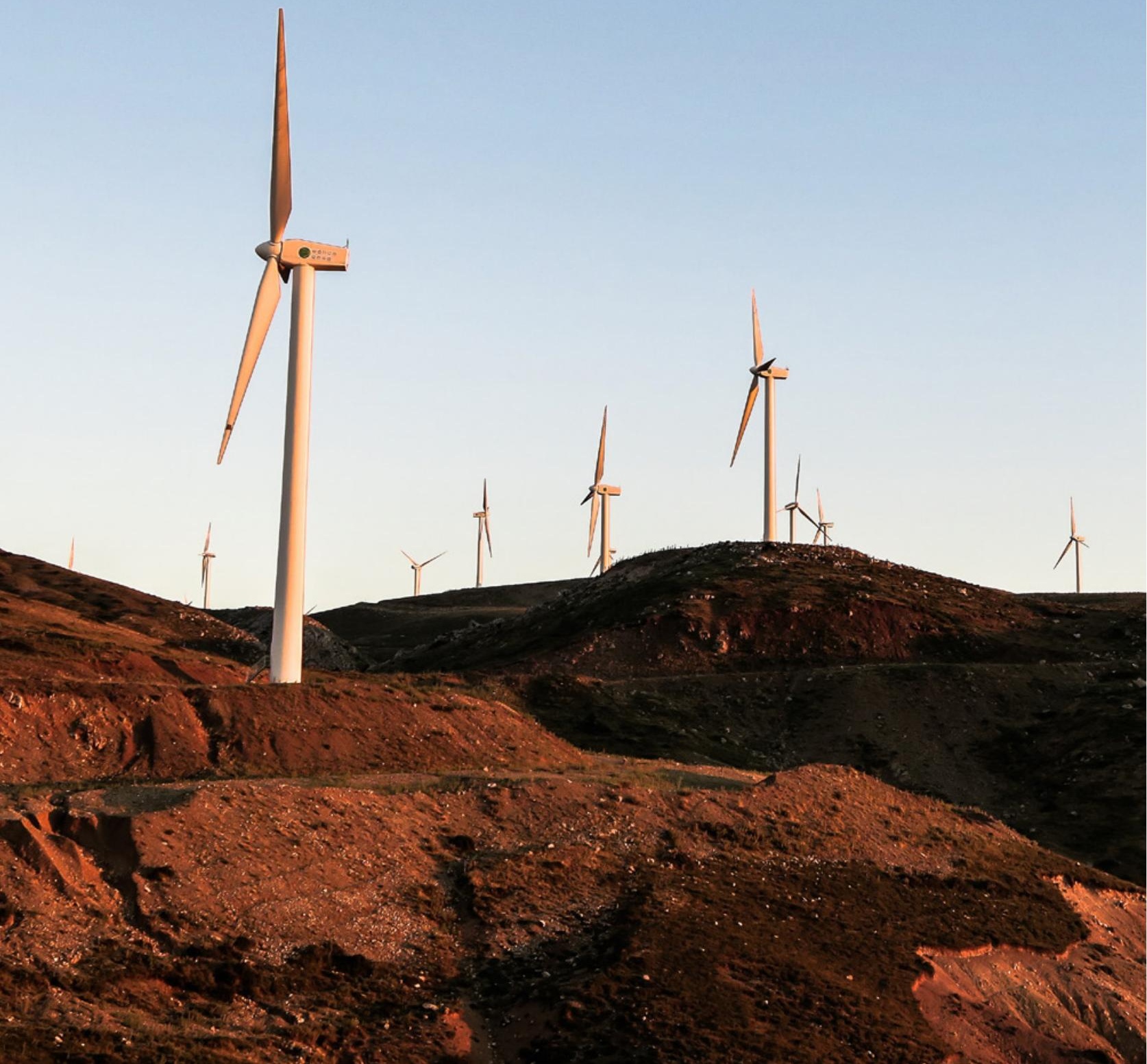




\section{Chapter 3}

\section{Countries implementing FFSR since 2014}

Many countries have reformed fossil-fuel subsidies since 2014

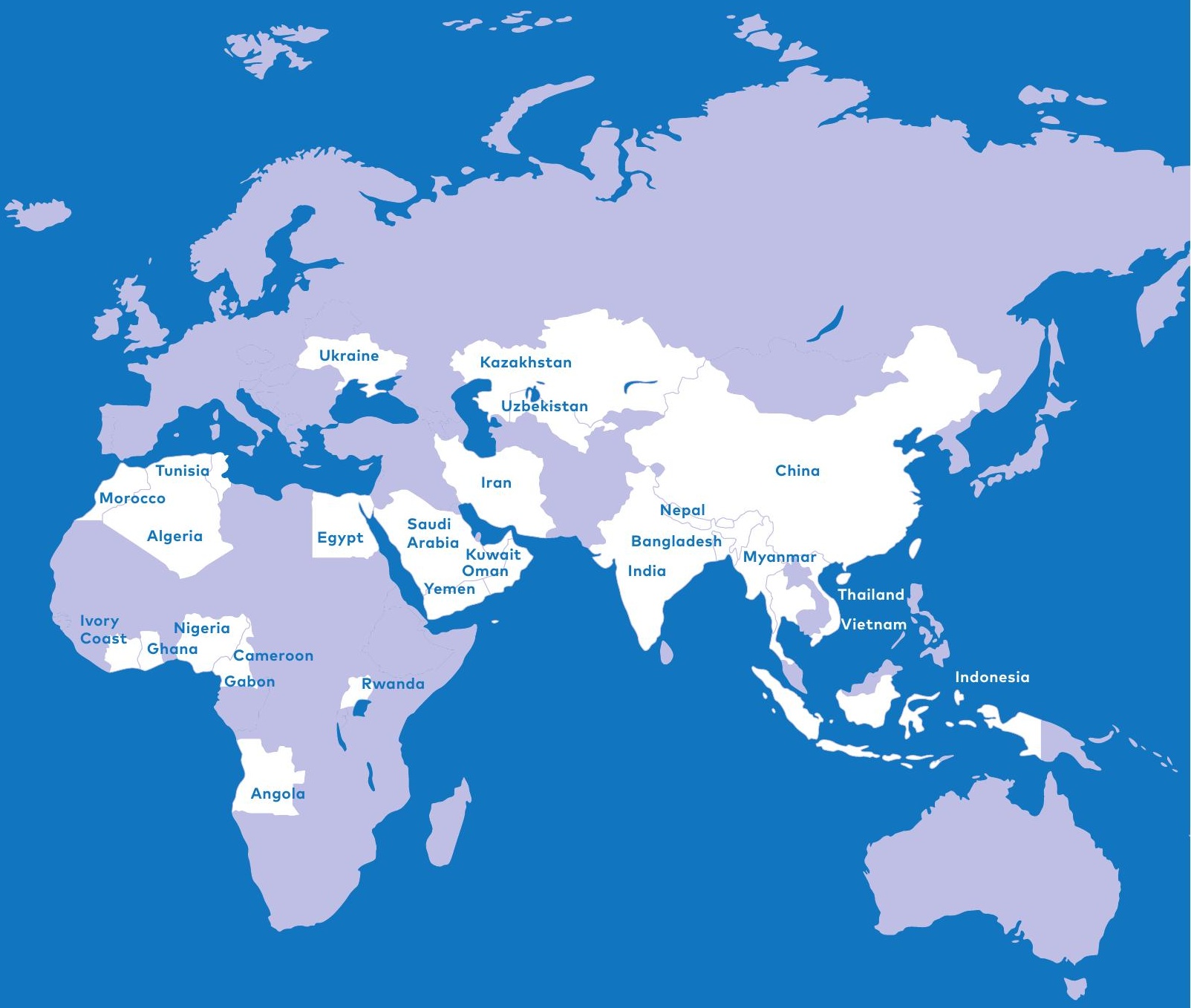




\section{Energy efficiency}

Decreases payback periods and increases private investment

\section{Domestic resources}

Are made available for governmments to invest in sustainable energy for all

\section{Innovation}

An increase in average energy prices increases new patents and innovation

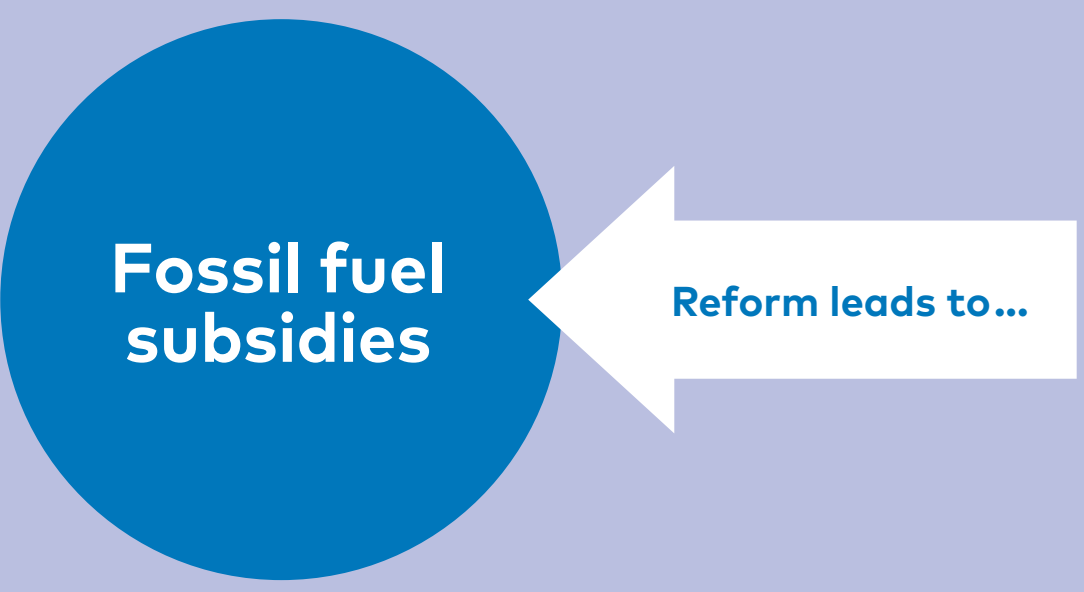

\section{Renewable energy}

Enables renewables to compete on a level playing field
Public transport

Becomes more economic to consumers in comparison to private car use
Carbon pricing and taxation

Follows from removal
of a negative price on
carbon (carbon tax or
straight VAT on fuel) 


\section{Chapter 4}

\section{Opportunities for Early Action}

As a policy tool, FFSR is a cost-effective means of carbon emissions reduction compared to other energy emission reduction tools. Most policy tools for removing carbon from national energy emission sources cost governments resources. The Norden study found that FFSR leads to an average annual saving to governments of close to USD 93 per tonne of GHG emissions removed (Merrill et al., 2015). Indeed, many countries recognise the growing importance of carbon pricing. Subsidies act as a negative price on carbon. Research undertaken by the IEA (2015b) estimated that 13 per cent of energy-related emissions received an incentive of USD 115 per tonne through a wide range of subsidies, and that only 11 per cent of energy-related emissions were subject to a carbon price (on average USD 7 per tonne).

Moreover, the removal of such subsidies can be the foundation for the successful implementation of many other energy climate policies: energy efficiency, renewables, innovation, carbon pricing and taxation, public transport infrastructure and the generation of domestic resources for the low-carbon energy transition. Morocco cited FFSR as part of a process of developing coherent energy and climate policies on launching its INDC in 2015 , and included the issue of reform.

Academics point to FFSR, along with decentralised modern energy for rural areas and fuel switching in the energy sector, as one of three feasible mitigation policy instruments to help reach a $2^{\circ} \mathrm{C}$ target (Jakob et al., 2014). The IEA (2015b) points to FFSR as one of five key measures to help bridge the gap between current commitments and the emissions reductions needed from the energy sector to stay within the $2^{\circ} \mathrm{C}$ warming target and en- 
courages the reform of consumer subsidies by 2030. A number of governments have followed the pathway below to understand the emissions reductions from the phase-out of fossil fuel subsidies using their own models (e.g., India) or by adapting others such as the GSI-Integrated Fiscal (IF) model (e.g., Morocco).

With a series of steps taken recently, India has cut subsidies and increased taxes on fossil fuels (petrol and diesel) turning a carbon subsidy regime into one of carbon taxation... In fact, over the past one year India has almost cut its petroleum subsidy by about 26\%. (India, 2015, p.27).

Many others have followed such leadership.

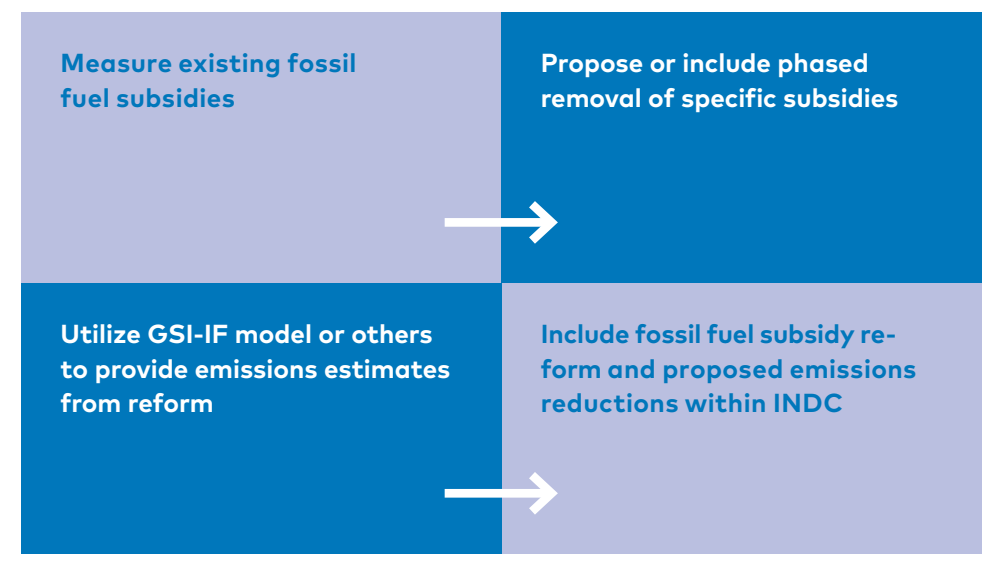

The Process of Including FFSR within Nationally Determined Contributions (NDCs) 


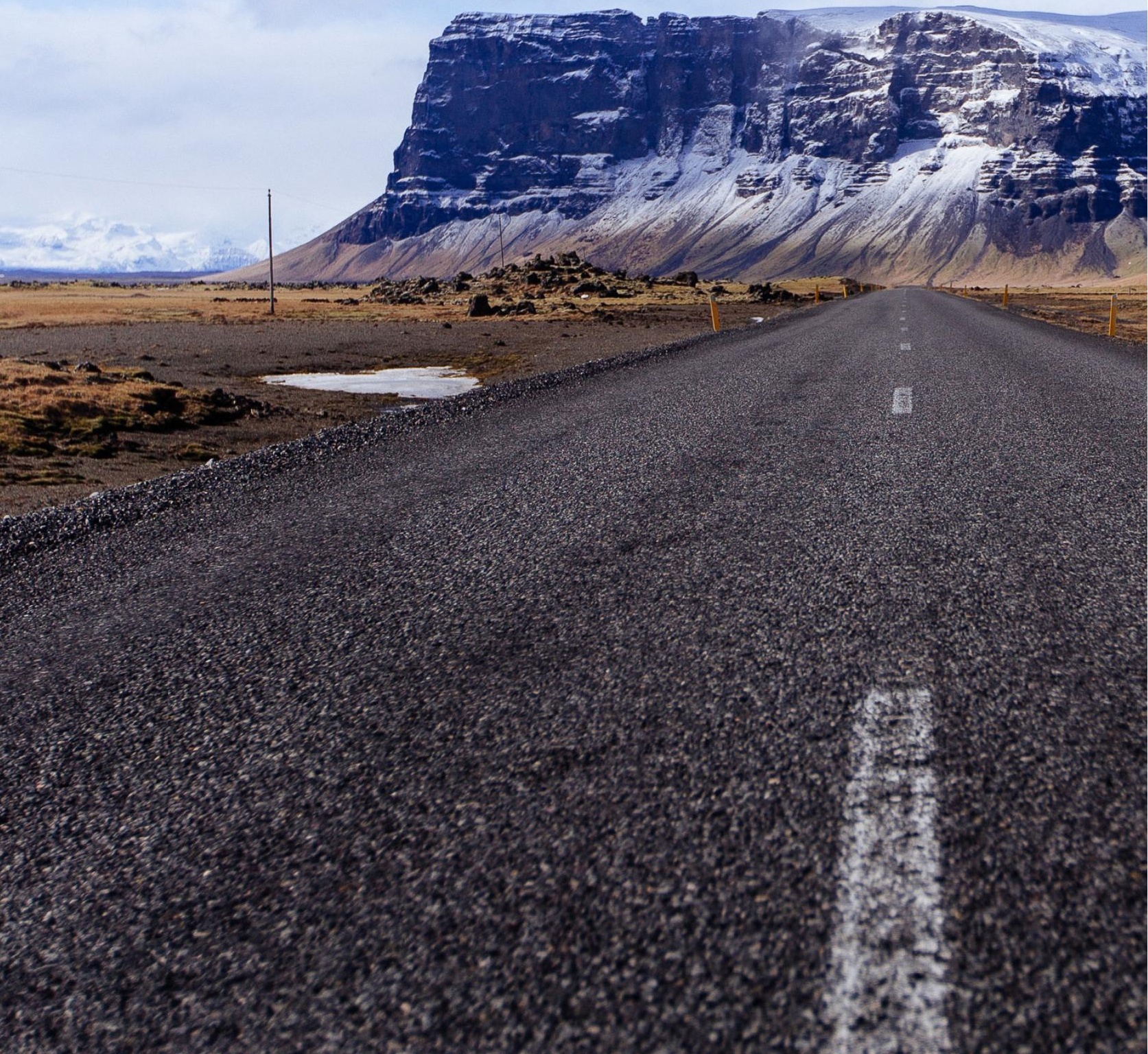



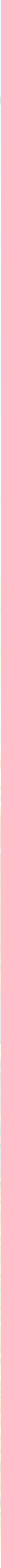


\section{Chapter 5}

\section{Morocco}

Morocco underwent a major reform of subsidies in 2013 focusing first on the most regressive subsidies to gasoline and diesel. Reform has been coupled with a commitment to increase the role of renewable energy, particularly solar energy. At the same time as reforming, the government expanded a national conditional cash transfer (CCT) system to cover many more families and a health insurance scheme for the poor. Morocco was an early supporter of the Fossil Fuel Subsidy Reform Communiqué and strongly included the issue within its INDC (July, 2015), and again in its NDC (September, 2016).

Energy reform in Morocco reduced fuel subsidy spending from 5.3 per cent of GDP in late 2011 to 1.1 per cent of GDP in early 2015. Subsidies on gasoline, diesel and fuel oil have been completely eliminated, resulting in annual fiscal savings of about USD 3 billion relative to 2011. Subsidy removal has led to increased domestic energy prices; between 2011 and early 2015, gasoline and diesel increased by 25 per cent and 35 per cent. Liquefied petroleum gas (LPG) subsidies, which were not included in recent reforms, amounted to approximately 1.1 per cent of GDP in 2015; the price has been frozen since 1995.

The Moroccan government has adopted a dual approach to mitigating the adverse impacts of energy price increases on low-income households. First, two existing nationwide social safety nets were significantly enlarged. The Tayssir CCT programme targeting poor rural households expanded from 80,000 families in 2009 to 466,000 families in 2014. Similarly, a health insurance scheme for the poor, Regime d'Assistance Medicale (RAMED), increased its coverage from 5.1 million ben- 
eficiaries in mid- 2013 to 8.4 million beneficiaries in early 2015 . The Tayssir CCT programme has had a significant impact on educational indicators since its creation in 2007. One study found that, over two years, the Tayssir-labelled cash transfers for educational support reduced the dropout rate by 76 per cent among those enrolled, increased re-entry by 82 per cent among those who had dropped out and cut the share of never schooled by 31 per cent.

Secondly, reforms have been decidedly 'pro-poor' in that the most regressive subsidies-those that benefit the poor the least-have been eliminated. One study estimated that only 1 per cent of gasoline and diesel subsidies accrued directly to the poorest 20 per cent of the population; low-income households were therefore relatively unaffected by the removal of this subsidy. Subsidies have been retained on products that, in Morocco, make up a larger share of household expenditure for the poor than for the rich: LPG, basic food items and electricity.

Furthermore, whilst subsidies on industrial fuel oil used in electricity generation were included in the 2014 subsidy reforms, an agreement between the government and the state-owned electricity generator allows for gradual increases to retail electricity prices between 2014 and 2017. The one exception to this is for the lowest consumption bracket (monthly use of less than 100 kilowatt-hours), which will remain exempt from tariff increases.

As well as reforming subsidies to remove subsidies to diesel and gasoline, and to better target subsidies to protect the poor in society, Morocco has combined this approach with ambitious renewable targets for the country. In June 2015, Morocco launched its INDC in Rabat. The head of State and the Minister of Environment highlighted the importance of reducing subsidies to fossil fuels as a matter of coherence in energy policy. 
The INDC outlines a vision for Morocco to 2030 and rests, to a large extent, on a major transformation of the energy sector, particularly due to increasing water stress. This transformation notably entails "substantially reducing fossil fuel subsidies, building on reforms already undertaken in recent years" and going for " $50 \%$ renewable energy electricity production by 2025 " (Morocco, 2015). Morocco reiterated these efforts to shift from a reliance on imports towards increasing the share of renewable energy in its updated NDC, including "substantially reducing public fossil fuel subsidies building on reforms already undertaken in recent years" (Morocco, 2016).

\section{Morocco has ambitious renewables targets of $2 \mathrm{GW}$ of wind power, 2 GW of solar power and to increase hydropower by $2 \mathrm{GW}$ of capacity by 2020 .}

This should represent 42 per cent of installed capacity by 2020 (OECD/IEA, 2014). Even before the recent subsidy reforms, the energy intensity index, a measure of the total primary energy supply per unit of GDP, had fallen by 4.5 per cent since 2000 , indicating energy is being used more efficiently. The increase in fossil fuel prices caused by FFSR is expected to reduce demand for these fuels, encourage fuel switching and further reduce energy intensity.

In Morocco the reduction in subsidies to fossil fuels has been coupled with a commitment to increasing targeted support to the poorest, as well as the role of renewable energy, particularly solar energy. The experience of Morocco shows the importance of a structured approach to subsidy reform and the need for high-level political engagement. 


\section{Chapter 6}

\section{The Philippines}

The Philippines removed various fossil fuel subsidies between 1996 and 2001 and experienced fuel price increases. As a result, it has been able to invest more in safety nets and renewable sources of energy, and now taxes fuels. Since reform, the Philippines has experienced a decline in the consumption of oil products, stabilised emissions per kilowatt-hour (kWh) generated, increased energy efficiency and reduced the energy intensity of the overall fuel mix. This is likely due to a mixture of reasons, including subsidy reform, the downturn from the Asian Financial crisis and higher oil prices being passed through to consumers, as well as active government policy to invest in renewables. The Philippines also endorsed the Fossil Fuel Subsidy Reform Communiqué in the lead-up to the Paris negotiations.

Many lessons about FFSR can be learned from The Philippines' experience. The country has removed all consumer energy subsidies, successfully phasing out price subsidies in the late 1990 s as a result of wider structural reform to deregulate both the downstream oil and electricity sectors. Crucially, this entailed removing the Oil Price Stabilization Fund and privatising the National Power Corporation. The Philippines is an importer of energy, and with rising energy prices the transition was managed through the use of targeted cash transfers and other regulated subsidies aimed at low-income households, specific sectors and certain socially sensitive fuels. These included a range of measures including: a transition period where prices were adjusted monthly; a lifeline rate for marginalised and low-income electricity users; a senior citizens' discount on electricity; and a one-off cash transfer (or Pantawid Kuryente) aimed at marginalised electricity consumers (those with a monthly consumption of $100 \mathrm{kWh}$ or less) to cush- 
ion the impact of rising electricity and fuel prices, funded from a value-added tax (VAT) levied on oil (katas ng VAT). Overall, 6.8 million households benefited, and the cost to the government was around USD 82 million. However, transaction and disbursement costs, leakage and exclusion rates were all high. Furthermore a Public Transport Assistance Programme (Pantawid Pasada) disbursed through debit and smart cards was targeted at jeepney and motorised tricycle operators whose fares are regulated and were unable to move with fuel price changes.

The Philippines has managed to turn energy from a drain on the government budget to a gain, by removing heavy fossil fuel subsidy expenditure and turning it into tax revenue. In 1996, direct government subsidy to the Oil Price Stabilization Fund stood at USD 343.5 million. The process of fossil fuel subsidy removal has also led to three independent inquiries (2005, 2008 and 2012), each reviewing the high domestic price of energy. Each concluded with a decision to remain with market-based pricing and a deregulated regime, and no return to the Oil Price Stabilization Fund.

The story of electricity pricing is similar: in 2001, when electricity privatisation was enacted, the total financial obligations of the National Power Corporation were more than USD 20.7 billion, with about 65 per cent due to obligations from one-sided "take-or-pay" contracts with independent power producers. In both cases, the major objectives of reform were to reduce the fiscal burden of energy subsidies, to introduce competition, to increase private sector participation and to ensure an efficient and reliable energy supply. 
The government has since targeted subsidies and policies toward expanding electricity networks and renewable forms of energy including through:

- A major reform of VAT in 2005 to finance short-term income support to the poor and long-term infrastructure, health and education programmes. VAT was raised to 12 per cent on gasoline; an excise tax was added; and a tax incentive was created by setting VAT at $O$ per cent for renewables.

- An expanded Rural Electrification Program aiming for 90 per cent household electrification by 2017.

- Introduction of the Renewable Energy Act of 2008, including income tax breaks, duty-free imports for equipment and accelerated depreciation.

- Introduction of an initial feed-in tariff (FIT) system for electricity produced from renewables and financing the rehabilitation of hydropower facilities in 2012.

- Investment in domestically produced electric tricycles.

Source: Mendoza (forthcoming, GSI-IISD) 



\section{Chapter 7}

\section{Ethiopia}

The story of FFSR in Ethiopia is widely regarded as a success. Ethiopia included the issue within its INDC: "Ethiopia has already removed fossil fuel subsidies to enable enhanced generation and use of clean and renewable energy" (Federal Democratic Republic of Ethiopia, 2015). From being a long-term, significant burden on the state budget, Ethiopia moved swiftly to remove all its fossil fuel subsidies in October 2008. Hardpressed by the need to free up monetary resources to tackle an urgent, national food crisis, the government increased diesel and kerosene prices by 40 and 50 per cent respectively (Carlisle, 2008; Kojima, 2009). Gasoline prices were also hiked.

Prior to reform, subsidies to fossil fuels totalled more than USD 600 million a year, or USD 50 million per month. To put the numbers into perspective, Ethiopia's subsidy expenditure was equal to 50 per cent of its total earnings from export. In addition, fuel subsidies ballooned its trade deficit and diverted much-needed resources away from areas such as food security, health and education (IISD-GSI, 2012). Also from a social point of view, fuel subsidies were performing badly, mainly benefitting higher-income households in urban areas and not the rural poor (Green Fiscal Policy Network, 2016).

As part of its subsidy regime, Ethiopia had put in place a fuel price stabilisation fund to help curb oil price volatility. The principle behind the fuel price stabilisation fund was to set domestic fuel prices higher than international prices when the latter are low. Savings are then accumulated into the fund to be disbursed for subsidising domestic fuel prices when international prices rise. However, as international oil prices rose steadily 
between 2004 and 2008, most fuel price stabilisation fund did not work well in practice. In Ethiopia, the fund racked up debts totalling 1.5 per cent of GDP (Kojima, 2009).

After reforming fuel subsidies in 2008, Ethiopia transitioned to an automatic pricing mechanism in order to adjust prices according to international price developments. The Ministry of Trade was charged with examining and adjusting prices on a monthly basis, although, in practice, adjustments happen less frequently (Energypedia, 2014). Nevertheless, Ethiopia has been able to successfully keep subsidies at bay since 2008 . It has also been able to build on the momentum from reform to take further steps to reduce fossil fuel energy consumption and actively pursue a green future.

As a direct consequence of reform, the government introduced the blending of ethanol and gasoline. Starting at 5 per cent ethanol in 2008, this was increased to 10 per cent in 2011. Reforms also led to a decrease in kerosene consumption and imports as well, as it allowed the government to invest in improved cook stoves for rural households, improving clean cooking facilities and energy efficiency across the country (Green Fiscal Policy Network, 2016).

Even more notably, since the implementation of reform in 2008, Ethiopia has been able to facilitate significant growth in electricity demand, increasing power generation capacity with about 200 per cent. By far the majority of this has come from renewable energy sources. In 2014, Ethiopia had a total installed generation capacity of 2,145 MW. More than 96 per cent came from renewable energy, primarily hydro (United States Agency for International Development, 2015).

To meet rising electricity demand, Ethiopia has also implemented policies to improve energy efficiency. For example, the government provided 5.3 million compact fluorescent light bulbs 


\begin{tabular}{|c|c|c|c|}
\hline \multicolumn{2}{|c|}{ Sources of Electric Power Generation, 2014} & \multicolumn{2}{|c|}{ Installed Capacity } \\
\hline & & (MWs) & Pct. of total \\
\hline \multirow{6}{*}{$\begin{array}{l}\text { Renewable } \\
\text { Energy }\end{array}$} & Hydro & 1890 & $88.1 \%$ \\
\hline & Geothermal & & $0.2 \%$ \\
\hline & Wind & 171 & $8.0 \%$ \\
\hline & Cogeneration & 0 & $0 \%$ \\
\hline & Imports & 0 & $0 \%$ \\
\hline & Total & 2066 & $96.3 \%$ \\
\hline \multirow{5}{*}{$\begin{array}{l}\text { Fossil } \\
\text { Fuels }\end{array}$} & MSD & 0 & $0 \%$ \\
\hline & Gas Turbines & 79 & $3.7 \%$ \\
\hline & HSD & 0 & $0 \%$ \\
\hline & Emergency Power Plants & 0 & $0 \%$ \\
\hline & Total & 79 & $3.7 \%$ \\
\hline \multicolumn{2}{|c|}{ Installed Capacity and Units Generated } & \multicolumn{2}{|c|}{$2,145 \mathrm{MW}$} \\
\hline
\end{tabular}

Sources of Ethiopia's Electric Power Generation, 2014

Source: United States Agency for International Development (2015)

free of charge. Even though the cost per bulb was USD 0.83, each bulb was estimated to save USD 3.5 for the electricity sector as a whole. Upon installation of half of the bulbs, Ethiopia's electricity sector saw a load reduction of approximately $80 \mathrm{MW}$. In comparison, this equals several times the total capacity of Liberia's electricity sector (IMF, 2013). These developments are well aligned with the government's official policy to become a middle-income country by 2025 while at the same time developing into a carbon-neutral economy (USAID, 2016).

Finally, it should also be noted that Ethiopia has used its own reform experiences to show international leadership on the issue by joining the Friends of Fossil Fuel Subsidy Reform (FFFSR). The FFFSR is a group of nine countries working to promote subsidy reform by sharing knowledge and policy experience at the international level. As part of this work, Ethiopia has endorsed the international Communiqué, calling on world leaders to accelerate the reform of fossil fuel subsidies. The Communiqué is currently backed by more than 40 governments around the world. 


\section{$=0$}
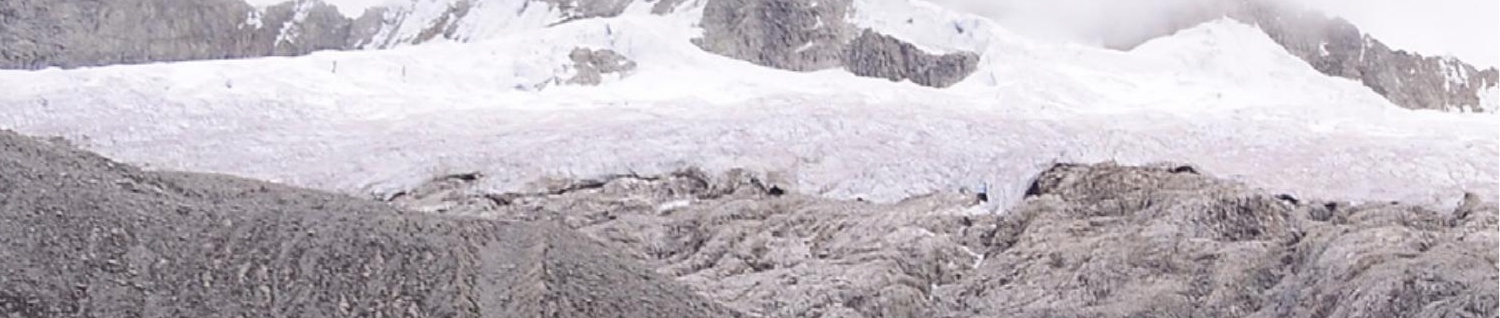

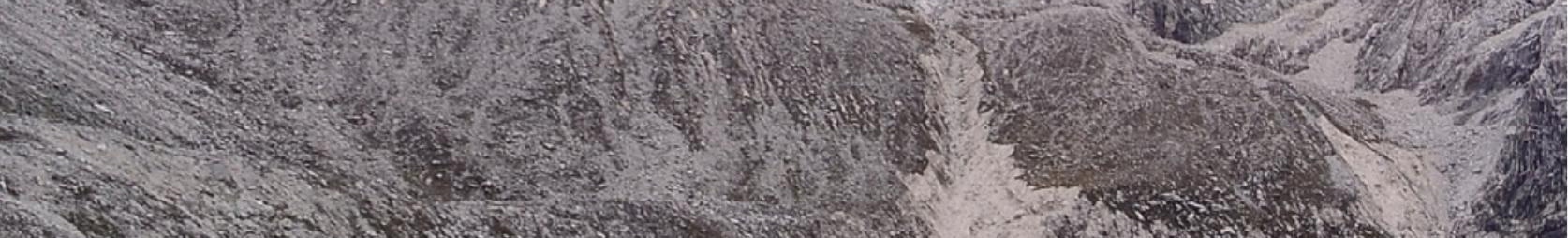

.

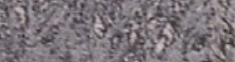

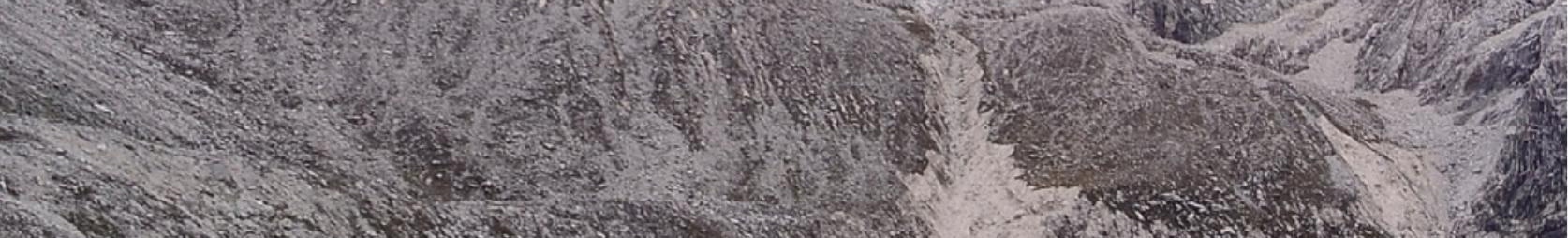

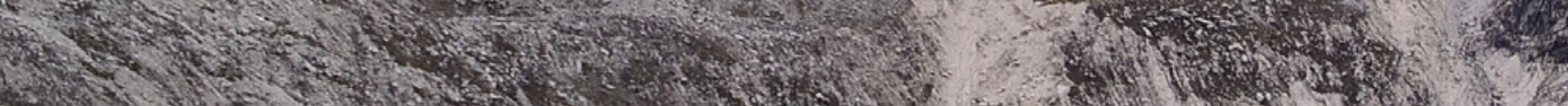

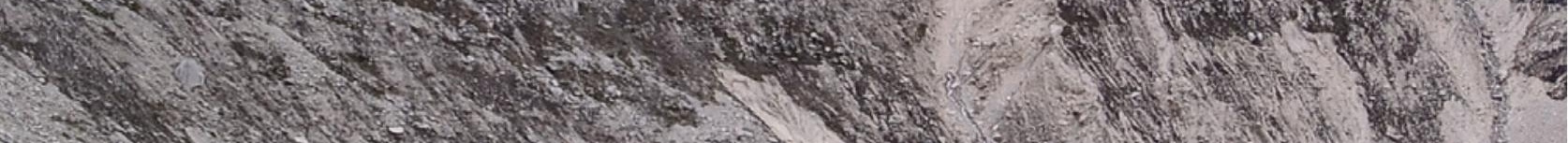

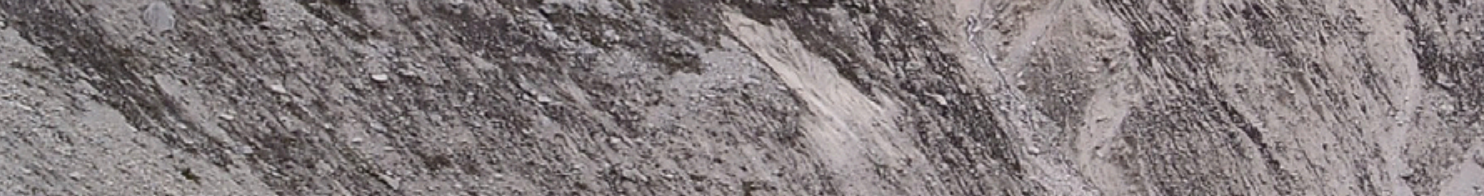

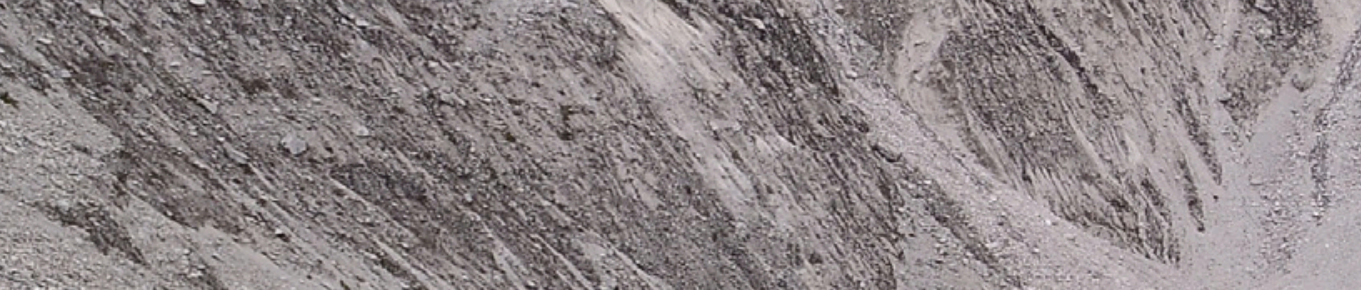
(5)

(3)

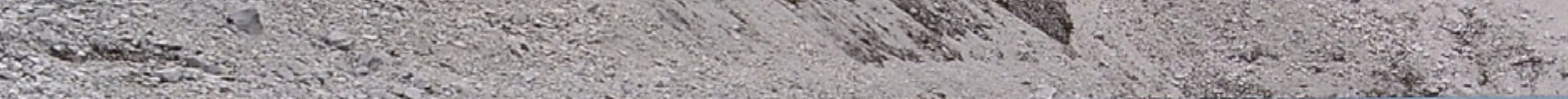

thes

2.

W. 1

$\sin$

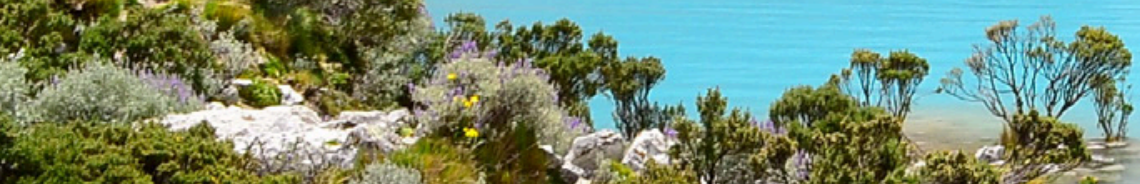

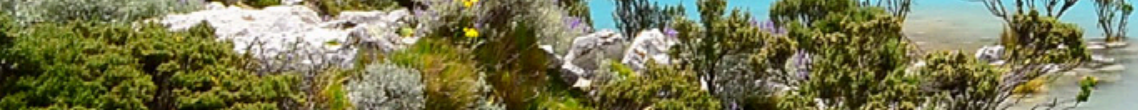

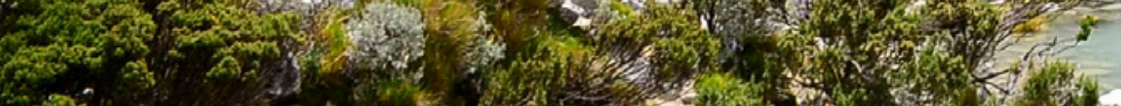

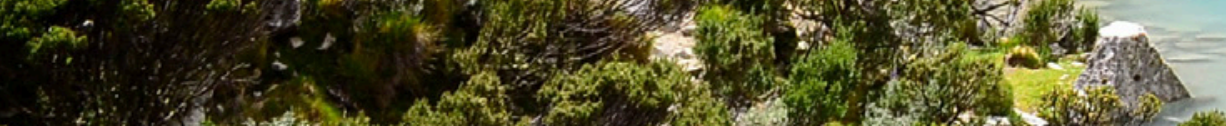

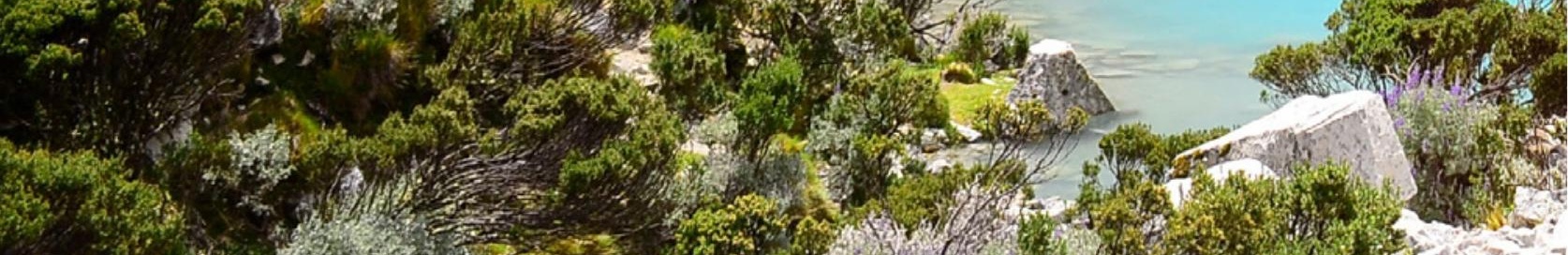

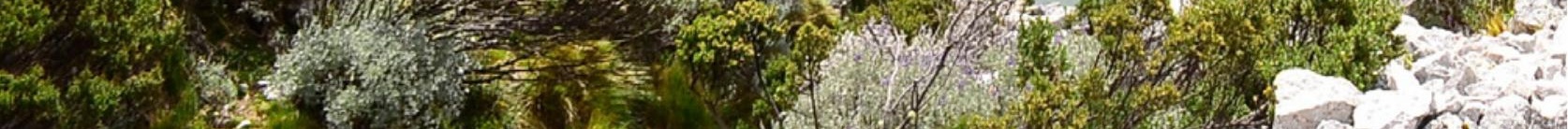




\section{Chapter 8}

\section{Peru}

Peru has also endorsed the Fossil Fuel Subsidy Reform Communiqué and was one of the first countries, along with New Zealand, to undergo peer review of its subsidies as part of the Asia-Pacific Economic Cooperation (APEC) commitment.

Since the 2000s, the country had counted on two main mechanisms to control the price of fossil fuels: the Fondo de Establilizacion de Precios de Combustibles (FEPC, Fuel Price Stabilisation Fund), established in 2004 to smooth international price volatility of gasoline, diesel, LPG and fuel oil; and tax exemptions to fossil fuel purchases in the Amazon region. Following the international oil price increases between 2006 and 2008, Peru's government froze the upper band of the FEPC, transforming the mechanism into a subsidy. Subsidies peaked at USD 1.7 billion, or 1.4 per cent of GDP, in 2008 (APEC, 2015). This represented an average transfer of USD 55 per person, although it is well documented that a disproportionate share of this accrued to higher-income households (e.g., Clements et al. 2013). Reductions in fuel excise taxes between 2004 and 2008 are estimated to have cost an additional 0.5 per cent of GDP per year (Vagliasindi, 2013).

The cost and unsustainability of the subsidies system lead to reforms. The fuel pricing system was revised, updating price bands every two months and reflecting international price movements of high-octane gasoline and regular gasoline between late 2011 and August 2012. Between 2009 and 2012, gasoline increased by around 75 per cent (Vagliasindi, 2013), diesel by 50 per cent (Kojima, 2013) and LPG by 5 per cent (APEC, 2015). 
To mitigate the effect of fossil fuel price increases, an existing CCT programme (Juntos) was expanded significantly, and the government introduced a cook stove distribution programme (LPG and improved biomass) in 2009 and a targeted LPG voucher scheme in 2012 (Fondo de Inclusión Social Energético or Social Inclusion Energy Fund [FISE]). By the end of 2014, around 1 million low-income families had been provided with an LPG or improved biomass cook stove, 900,000 families were receiving monthly LPG vouchers and 800,000 families were benefiting from regular cash transfers.

The main element of FISE is an LPG voucher scheme: eligible families receive a coupon entitling them to a monthly discount of PEN 16 (USS 5.70) on a first refill of a $10 \mathrm{~kg}$ LPG container. FISE is revenue-neutral, funded via surcharges on industrial electricity users, liquid fuel producers and importers, and natural gas consumers. According to APEC (2015), the total cost of the FISE programme is PEN 230.4 million (USD 82 million), implying that the programme reaches 1.2 million households each year. It is interesting to note that the subsidy per person is around USD 17, three times lower than the fossil fuel subsidies in 2008. Furthermore, the percentage of Peruvian households benefitting from improved cook stoves increased from 3.6 per cent in early 2010 to 11.5 per cent cent in mid-2012 (Sustainable Energy for All, 2013). This impressive increase is due to ongoing programmes by the government and non-governmental organisations in rural areas where LPG distribution is difficult.

Another pillar of FISE is to promote renewable energies, especially in remote areas, but concrete financing still has to be defined. Peru produces oil and natural gas, but it is a net importer of oil and a net exporter of natural gas, notably since the development Camisea field in 2005 (IEA, 2013). 


\begin{tabular}{l|l|l|l|l} 
& $\begin{array}{l}\text { Subsidy \% } \\
\text { GDP }\end{array}$ & $\begin{array}{l}\text { Subsidy USD } \\
\text { billions }\end{array}$ & $\begin{array}{l}\text { Coverage } \\
\text { millions ppl }\end{array}$ & $\begin{array}{l}\text { Subsidy } \\
\text { USD/person }\end{array}$ \\
$\begin{array}{l}\text { Total fuel } \\
\text { subsidy (peak) }\end{array}$ & 1.4 & 1.70 & 30.8 & 55 (per capita) \\
\hline $\begin{array}{l}\text { Total fuel } \\
\text { subsidy (201) }\end{array}$ & 0.51 & 0.87 & 30.8 & 28 (per capita) \\
\hline $\begin{array}{l}\text { FISE (2015) } \\
\text { Improved } \\
\text { Cook Stoves } \\
\text { (2009-2014): } \\
\text { ICSPWS }\end{array}$ & $0.041 \%$ & 0.08 & 4.8 & 17 \\
\hline
\end{tabular}

Phase-out and targetting of fuel subsidies in Peru

Source: Kitson et al. (2016)

Peru's National Energy Plan 2014- 2025 contemplates adding 1'200 MW of new hydro capacity by 2020-2021. The target for non-hydro renewables is to reach 5 per cent of the total energy mix. Renewables will be centered on rural electrification, via hybrid systems (photovoltaic solar and diesel) and additional promotion of wind, solar and biomass. With that purpose, the country has created ADINELSA, a state-owned asset-holding company that manages more isolated and less profitable rural systems. The plan is also declaring energy efficiency in residential, industrial, public and transportation sectors as a "national interest."It expects to have energy efficiency labels in all these sectors within 10 years (Ministerio de Energía y Minas, 2014).

To conclude, Peru sets an example of FFSR combined with targeted government support towards CCTs, vouchers and targeted cook stoves, demonstrating improved targeting, savings on previous blanket fossil fuel subsidies and positive impacts for low-income households. 


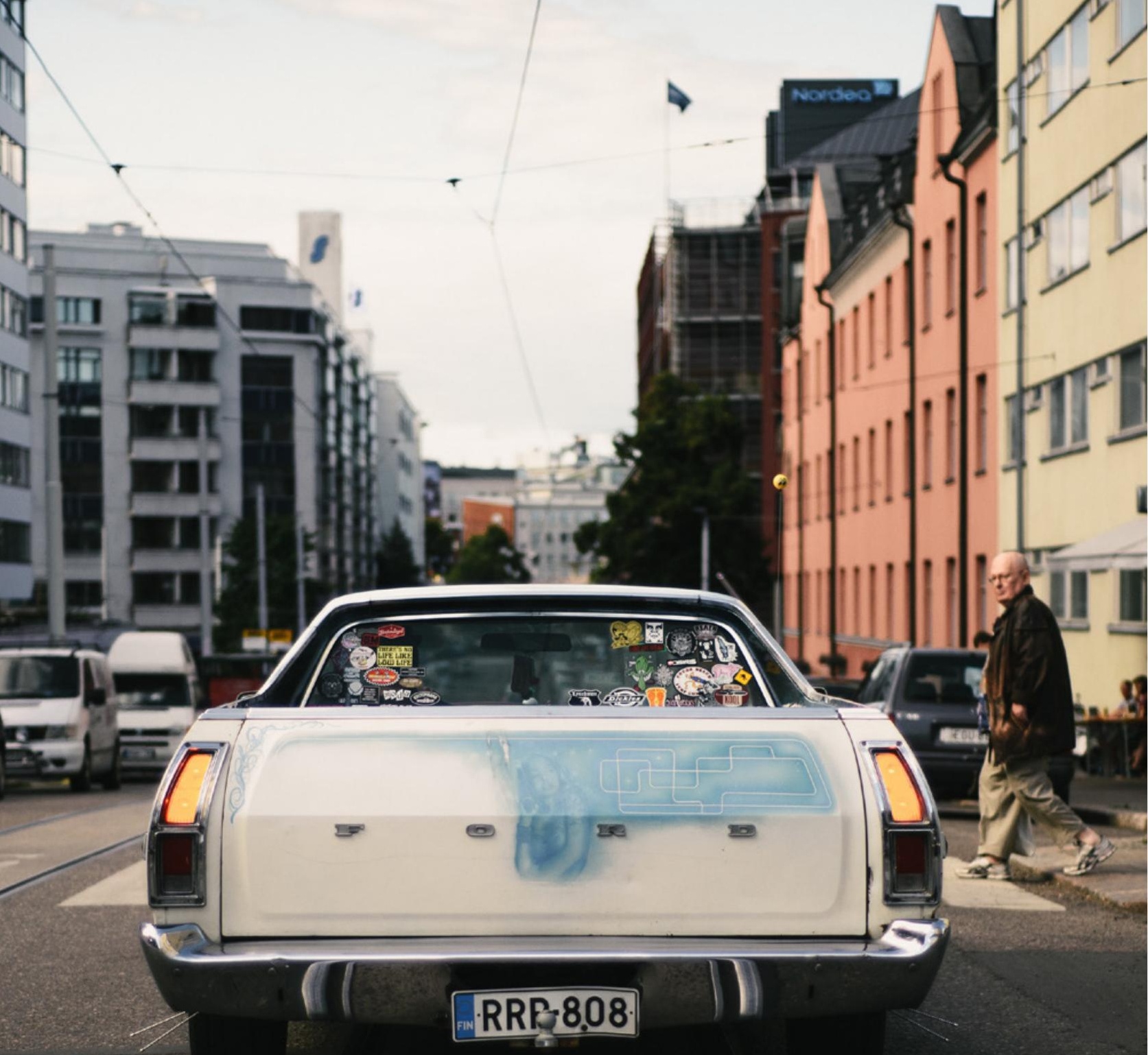




\section{Chapter 9}

\section{Nordics}

The Nordic countries have set ambitious national environmental targets. Where the European Union (EU) aims for 20 per cent reduction in greenhouse gas emissions by 2020 from 1990 levels, most Nordic countries strive for 30-40 per cent reductions and have even higher targets for renewable fuels in energy consumption. Looking further ahead, Denmark, Norway and Sweden have goals for 100 per cent renewable energy in energy and transport sectors and total carbon neutrality, the latest by 2050 (Bragadóttir, Danielsson, Magnusson, Seppänen, 2014).

Energy and climate policy in the Nordics has undergone strengthening and steering in the recent years both for fiscal and environmental reasons. Finland and Denmark have lately introduced tax reforms to increase the cost of fossil fuels, whereas Sweden and Norway have reformed carbon dioxide taxation to include new sectors.

In the transportation sector, Finland, Denmark and Iceland have introduced emission-based vehicle taxes. Also, Sweden raised vehicle taxes and, along with Iceland and Norway, offers discounts for environmentally friendly cars (Bragadóttir et al., 2014). The Nordic countries have several innovative instruments to direct development towards rapid detachment from fossil fuel dependence. 


\section{Traffic light system for assessing the harmfulness of subsidies (Finland)}

Finland has identified the need to rationalise its subsidy policies and to remove subsidies for fossil fuels. As part of an assessment based on the years 2009-2014, a total of 400 subsidy measures covering tax support and exemptions, budget support and other instruments have been investigated and categorised based on their environmental harmfulness. The categorisation is based on a transparent traffic light system, signalling "good, bad and ugly" subsidies. Good subsidies are targeted due to their positive environmental impacts, whereas bad subsidies are a possible waste of money and ugly subsidies have potential negative environmental impacts (Ministry of Finance 2016).

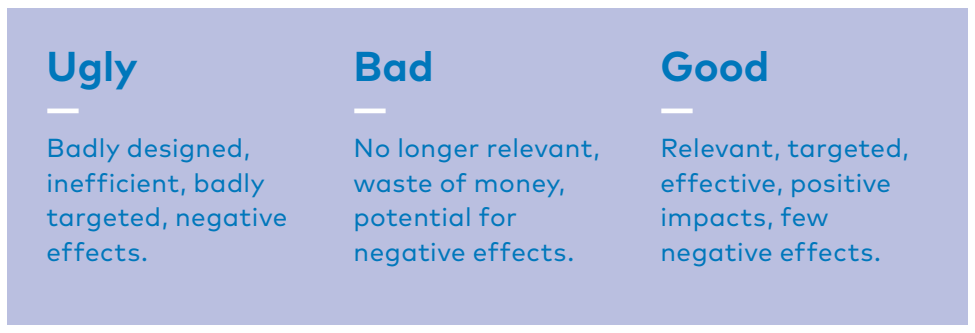

The assessment signalled that potentially harmful subsidies reside especially in energy, transport and agriculture sectors. The energy sector alone accounted for EUR 800 million of potentially harmful subsidies annually (Ministry of Finance, 2016)

The introduction of the traffic light system has contributed to subsidy reforms such as the increase in transportation fuel, vehicle, energy and carbon dioxide taxation. 


\section{Heat pumps replacing \\ heating oil (Sweden)}

In a broad tax reform in the early 1990s, Sweden introduced new energy taxes and a carbon dioxide tax. This was followed by support for a 30 per cent material and construction costs offered to households to switch from oil or electric heating to district heating, heat pumps or bio-based heating in 20062010. As a result, heating oil consumption dropped from more than 30 TWh in 1990 to a few TWh's in 2013 (in apartments, houses and commercial buildings) (EM 2015). In addition, electric heating decreased by approximately 6 terawatt-hours (TWh), while the adoption rates of heat pumps sold annually rose from approximately 25,000 in 2000 to some 127,000 in 2010 (18 per cent) (Energimyndigheten, 2015). By 2008, 20 per cent of Swedish houses had a heat pump installed in 90 per cent of new houses (Energimyndigheten, 2009). Furthermore, heat pumps produced approximately 22.5 TWh of heat (with input of about 7.5 TWh of electricity) equaling roughly 40 per cent of the volume of district heating.

\section{Electric cars as a fast track for de-fossilising the transportation sector (Norway)}

Norway is a world leader in purchase incentives for electric vehicles (IEA, 2016a). The incentive scheme for zero emission cars has been shaping since 1990s in a twofold approach, with benefits on both the cost and usage of electric car (Haugneland, Bu, Hauge, 2016). Electric vehicles are exempted from registration fee and most importantly from the VAT, which is normally 25 per cent for goods and services (IEA, 2016a). There is also a reduced annual vehicle fee and a 50 per cent discount on company car tax. Electric vehicles have free charging and parking, exemption from tolls as well as access to public lanes. Along with purchase incentives, some Norwegian cities also financially support the charging infrastructure, which has made it convenient to use an electric vehicle (Haugneland et al., 2016). 
By September 2016, Norway has achieved:

$-116,000$ electric vehicles sold; among these, 90,000 battery and 26,000 chargeable hybrid cars (Norsk Elbilforening, 2016).

- 1.5 per cent electric vehicles per capita in 2015, the highest percentage in the world (IEA, 2016a).

- A market share of 23 per cent for all new cars sold (IEA, 2016a).

- $93.5 \mathrm{~g} / \mathrm{km}$ average carbon dioxide emissions in new cars (OFV, 2016).

\section{Pioneering in wind power}

\section{(Denmark)}

Denmark is considered the "cradle of modern wind energy technology," and was the first European country to introduce a large subsidy scheme for wind power in 1993 (IRENA, 2013). The scheme was a combination of price guarantee and tax reduction and led to rapid growth in wind power capacity in the second half of the 1990s (IRENA, 2013). The support scheme has been running ever since (with adjustments along the way) and in 25 years (1990-2015), the share of wind power in Danish power production has increased from 3 per cent to 42 per cent, mainly replacing coal (IEA, 2016b).

Key elements of the Danish support policy success include its long-term focus, stable and secure revenue for investors, and its expression of political commitment from the government, all of which have decreased investor risk (IRENA, 2013). The major increase in wind power production has also supported local industries. In 2015, Denmark wind turbine industry generated EUR 10 billion in annual revenue and created 30,000 jobs (Danish Wind Industry Association 2016). 
Purchase incentives and market shares

of electric vehicles in Norway. (IEA, 2016a)

- Plug-in Hybrid Electric vehicle (PHEVs) Battery Electric vehicle (BEVs) - BEV market share PHEVs market share

$$
25.000
$$

$20 \%$

$$
20.000
$$
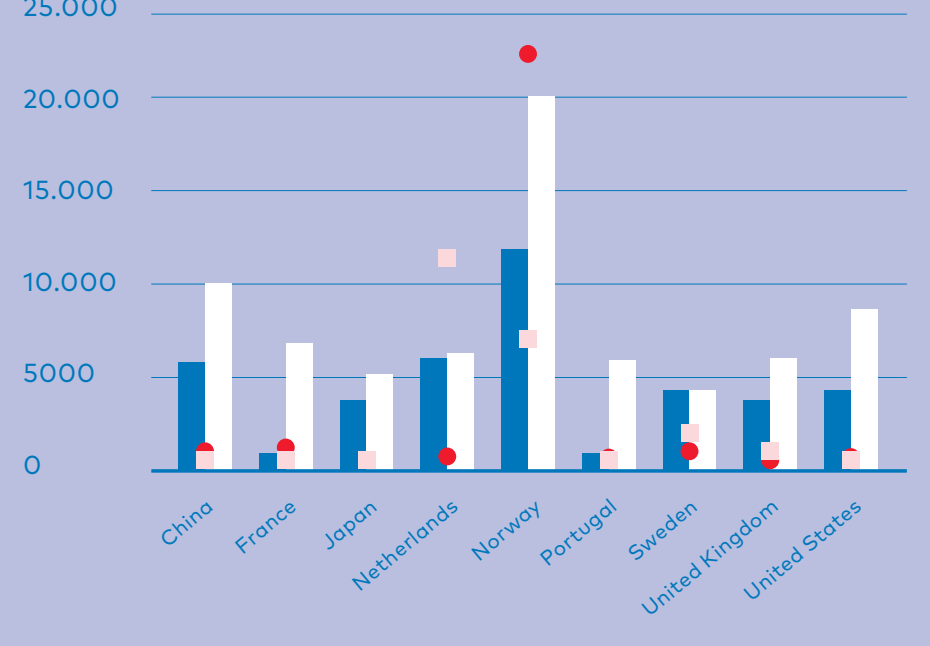

Danish wind power generation 1991-2015

Source: ENS (2016)

TWH

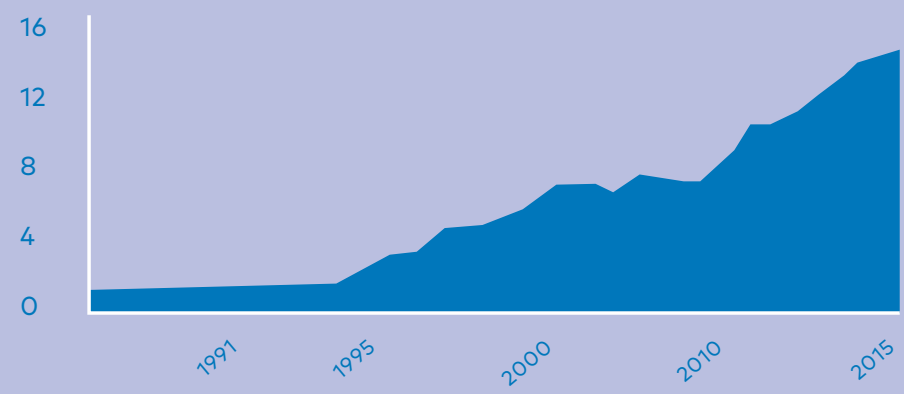




\section{Chapter 10}

\section{Nordic Leadership and Support on FFSR}

The Friends of Fossil Fuel Subsidy Reform and the Fossil Fuel Subsidy Reform Communiqué.

Denmark, Finland, Norway and Sweden are members of the Friends of Fossil Fuel Subsidy Reform, along with Costa Rica, Ethiopia, New Zealand, Switzerland and Uruguay. The Friends were established in June 2010 to support G2O and APEC leaders' commitments to phase out inefficient fossil fuel subsidies. In April 2015, the Friends launched the Fossil Fuel Subsidy Reform Communiqué at the annual World Bank Springs along with the support of the United States and France. The Communiqué encourages the international community to advance FFSR through three principles.

- Increased transparency around fossil fuel subsidies

- Ambitious reform

- Targeted support to ensure reforms are implemented in a manner that safeguards the poorest

The Communiqué was presented to countries for endorsement at various international events throughout 2015, including the Bonn meetings in the lead-up to Paris, Financing for Development in Ethiopia, as part of the SDGs, the Clean Energy Summit, and it built momentum throughout the year. The Communiqué was handed over by world leaders to the then UNFCCC Executive Secretary Christiana Figueres at COP 21 in Paris, in November 2015, to support efforts to reach a new global climate agreement. 


\section{Countries endorsing the Fossil Fuel Subsidy Reform Communiquié}

Austria $\cdot$ Canada $\cdot$ Chile $\cdot$ Colombia $\cdot$ Cook Islands $\cdot$ Costa Rica $\cdot$ Croatia $\cdot$ Cyprus Czech Republic · Denmark · (Opposite page) Estonia · Ethiopia · Finland · France

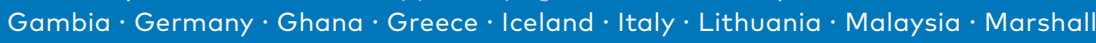
Islands · Mexico $\cdot$ Moldova $\cdot$ Monaco $\cdot$ Morocco $\cdot$ Mozambique $\cdot$ Netherlands New Zealand · Norway · Peru · The Philippines · Samoa · Sweden S Switzerland Tuvalu $\cdot$ Uganda $\cdot$ United Kingdom · United States $\cdot$ Uruguay $\cdot$ Vanuatu

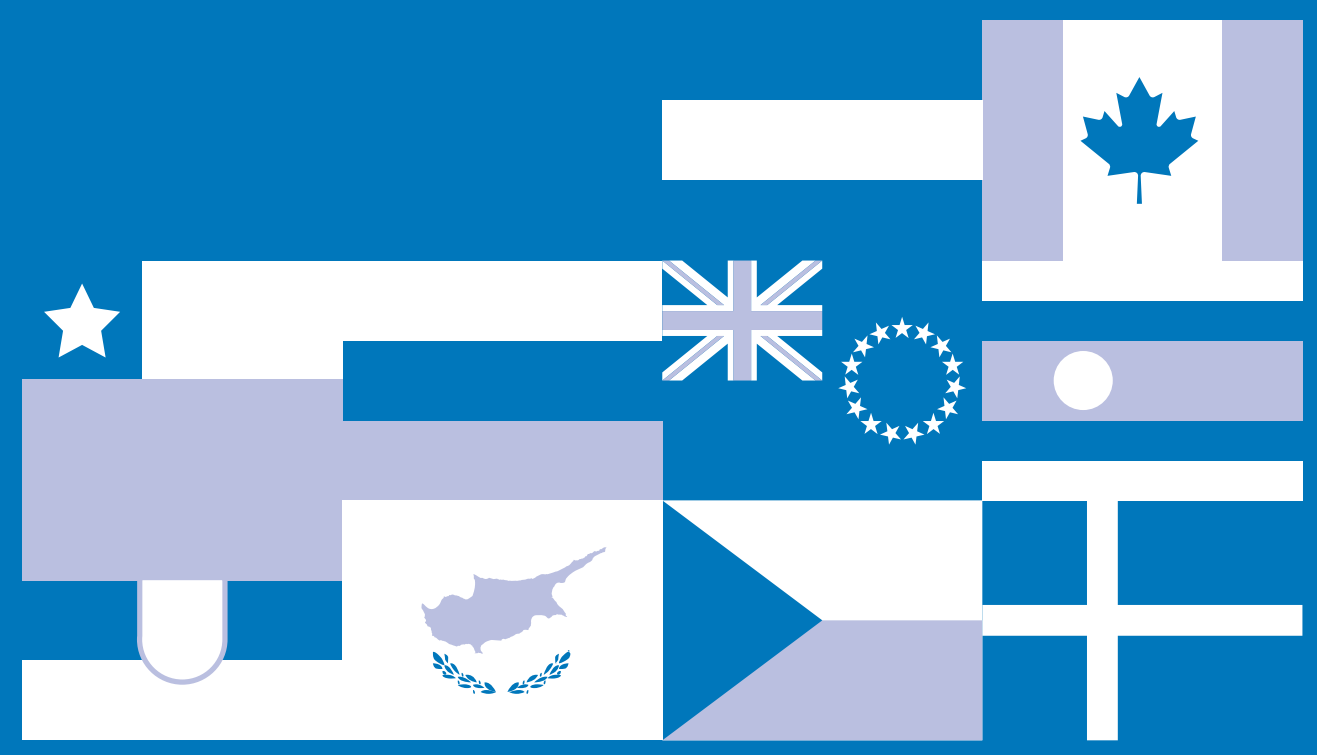




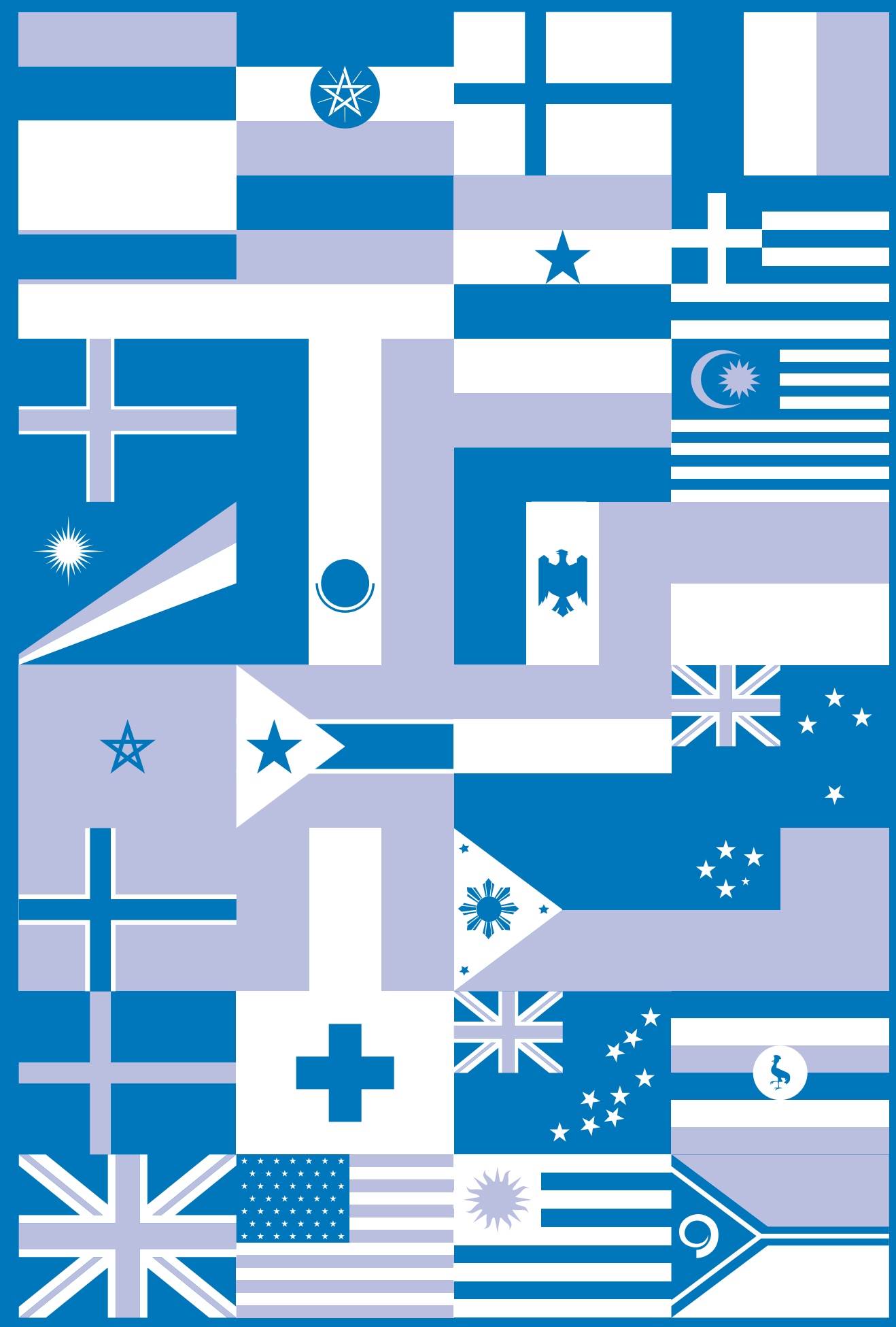


The Communiqué (available at www.fffsr.org ) has gained the backing of over 40 countries, and the support and backing of business associations representing close to 15,000 businesses and investors, as well as non-governmental and international organisations.

The Communiqué enabled Nordics, as part of the Friends, to develop peer-to-peer discussions and raise awareness around fossil fuel subsidies and their reform with countries, and to raise support for the 2015 Paris Agreement of the UNFCCC.

\section{Support to organisations to work on reform}

Nordics have not only added their political weight behind FFSR, but also financial support for those organisations working actively with countries on reforms, such as the World Bank, the International Monetary Fund, the Organisation for Economic Co-operation and Development, the International Energy Agency and the Global Subsidies Initiative of IISD. Finland recently included the FFSR within an initiative to support developing countries' tax capacity that includes reducing fossil fuel subsidies and reforming excise duties, particularly within the EU but also with partner countries. Sweden included the issue of support to partner countries undergoing FFSR through its 2013 Aid Policy Framework.

As a joint body, the Nordic Council of Ministers has also funded work researching and disseminating information on the topic of reform with international policy-makers as part of the joint Prime Ministers Green Growth Initiative. In 2012 the Nordic Council of Ministers (NCM) published the Nordic Environmental Action Plan 2013-2018. As part of this plan, Nordic countries agreed to "work to phase out subsidies to fossil-fuels and introduce taxes that reflect environmental impact. 
This will provide the right incentives to reduce emissions from energy and transport, including international shipping and aviation" (NCM, 2012).

The NCM funded a research project that shows how countries can phase out ineffective and environmentally harmful public subsidies to fossil fuels. National energy models were developed using the GSI-Integrated Fiscal model, and research results indicate that a reform of these subsidies could reduce global carbon dioxide emissions considerably. The project worked with and across 20 emerging and developing countries in the lead up to the Paris negotiations. Throughout 2015 the research was fed into international processes: the Sustainable Development Goals, Financing for Development and the UNFCCC, and shared directly with climate negotiators. Country-focused webinars and side events reinforced the issue in Geneva, Bonn and Paris. The research complimented Nordic efforts as part of the Friends of Fossil Fuel Subsidy Reform international Communiqué. Fourteen countries included the issue within their national climate contributions. This included Morocco, with which the project worked closely, in line with its ambitious plans for the expansion of renewable energy, efficiency and access.

Nordic countries, via NOAK (the Nordic working group for global climate negotiations), continue to move this issue up the agenda and to work with partner countries to make the switch from fossil fuels towards sustainable energy. NOAK aims to do this through working with countries on practical project proposals for FFSR and redirection towards sustainable energy for all. This brochure sets out to highlight the many leaders on and opportunities arising from this change in policy, which others can learn from.
For more information about the project please contact the NOAK coordinator, Outi Leskelä:

Outi.Leskela@ym.fi 
References 
APEC. (2015).

Peer Review on Fossil Fuel

Subsidy Reforms in Peru

Bragadóttir, H., Danielsson,

C. v. U., Magnusson, R.

Seppänen, S. (2014).

The use of economic

instruments in Nordic

environmental policy 2010-

2013. TemaNord 2014

Carlisle,. T. (2008, October 4).

Ethiopia end fuel subsidy

and moves to stabilise

food prices.

Coady, D., Parry, I., Sears,

L., \& Shang, B. 2015.

(2015).

How large are global

energy subsidies?

(IMF Working Paper

15/105). Paris: IMF.

Clements, B. et al. (2013).

Energy subsidy reform:

Lessons and recommen-

dations.

Davis, L. W. (2013).

The economic cost of

global fuel subsidies.

National Bureau of

Economic Research.

Danish Wind Industry

Association. (2016, June 28).

2015 was a year of both

ups and downs for the

Danish wind industry.

Energypedia.

(2014, July 15).

Fuel prices Ethiopia.

Energimyndigheten. 2009).

Sverige ledande på

värmepumpar: Heta

värmepumpar.

Energimyndigheten. (2015).

Värmepumparnas roll på uppvärmningsmarknaden. Utveckling och konkurrens $i$ ett föränderligt energisystem.

ENS. (2016)

Data for eksisterende og

afmeldte moller.

The Friends of Fossil Fuel

Subsidy Reform. (2016).

Fossil-Fuel Subsidy Reform

Communiqué.

Federal Democratic

Republic of Ethiopia, 2015

'Intended Nationally
Determined Contribution (INDC) of the Federal

Democratic Republic

of Ethiopia' available

from UNFCCC.

GIZ 2015 and 2016,

Fuel Price News

QSI International Institute for Sustainable Development. (2012, March 26).

Fossil-fuel subsidy reform: Building momentum at Rio and beyond.

Green Fiscal Policy

Network. (2016).

Ethiopia.

India, 2015 'India's Intended Nationally Determined Contribution', available from UNFCCC.

International Energy

Agency (IEA). ( 2014).

Energy efficiency Market

Report 2014

International Energy

Agency (IEA). (2015a).

World energy outlook 2015.

Paris: IEA/OECD.

International Energy

Agency (IEA). (2015b)

Energy and climate change

(World Energy Outlook

Special Report). Paris:

IEA/OECD

International Energy

Agency (IEA). (2016a).

Global EV Outlook

2016: Beyond one

million electric cars.

International Energy

Agency (IEA). (2016b).

Denmark electricity

and heat.

International Monetary

Fund. (2013).

Energy subsidy reform in sub-Saharan Africa:

Experiences and lessons Washington, D.C.: IMF. IRENA. (2013).

30 years of policies for wind energy: Lessons from 12 wind energy markets. International Renewable Energy Agency.

Jakob, M., Steckel, J. C., Klasen, S., Lay, J. Grunewald, N., MartínezZarzoso, I. et al. (2014).
Feasible mitigation actions in developing countries.

Nature Climate Change, 4, 961-968.

Kitson, L., Merrill, L., Beaton, C., Sharma, S., McCarthy, A., Singh, C., Sharma, A., Parikh, J., Ohaeri, V.I., Chowdhury, T. T. (2016, August). 'Gender and fossil fuel subsidy reform: Current status of research' Geneva/Winnipeg: GSI-IISD.

Kojima, M. (2009).

Government response

to oil price volatility:

Experience of 49 developing

countries, The World Bank.

Mendoza, M.N.,

(forthcoming).

'Lessons learned: Fossil

fuel subsidies and energy

sector reform in the

Philippines.' Geneva/

Winnipeg: GSI-IISD.

Ministry of Finance. (2016).

Structural Policy Unit

slides. 'Assessment and

reform of fossil fuel

subsidies in Finland.

Merrill, L., Bassi, A.M., Bridle, R. \& Christensen, L.T. (2015). Tackling fossil fuel subsidies and climate change: Levelling the energy playing field. Norden.

Ministerio de Energía y Minas (2014). Plan Energético Nacional 2014-2025.

Morocco, 2015

'Morocco Intended

Nationally Determined

Contribution (INDC)

Under the UNFCCC',

available from UNFCCC.

Nordic Council of Ministers (NCM). (2012).

Nordic Environmental

Action Plan 2013-2018.

Norsk elbilforening (2016)

Norwegian EV market

OECD/IEA (2014).

Morocco 2014-

Energy Policies Beyond

IEA Countries.
OFV 2016

www.ofv.no/forside/

Parry, I., Heine, D., Lis, E., Li, S., \& Sears, L. (2014).

Getting energy prices right: from principles to practice. Paris: IMF.

Pradiptyo, R., Susamto, A., Wirotomo, A., Adisasmita, A. \& Beaton, C. (2015).

Financing development with fossil fuel subsidies: The reallocation of Indonesia's gasoline and diesel subsidies in 2015. Winnipeg/Geneva: IISD-GSI

Stefanski, R.(2016), p.1)

'Into the Mire:

A Closer Look at Fossil

Fuel Subsidies', University of Calgary, The School of Public Policy Vol 9, Issue 10, March 2016.

Sustainable Energy for All. (2013). Global tracking framework. Washington, D.C.: ESMAP and IEA.

Terton, A., Gass, P., Merrill, L., Wagner, A., \& Meyer, E. (2015).

Fiscal instruments in INDCs: How countries are looking to fiscal policies to support INDC implementation.

United Nations Framework Convention on Climate Change. (2016). Adoption of the Paris Agreement.

United Nations. (2015).

Addis Ababa Action

Agenda on Financing for Development.

United States Agency for International Development. (2015). Power Africa: Investment brief for the energy sector in Ethiopia.

Vagliasindi, M. (2013).

Implementing energy subsidy reforms. Evidence from Developing Countries. 


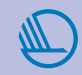

Nordic Council of Ministers

Ved Stranden 18

DK-1061 Copenhagen K

www.norden.org

If we aim to reduce global emissions in order to limit global warming to less than $2^{\circ} \mathrm{C}$ above pre-industrial levels, then the energy sector is of paramount importance. A critical change will be national fuel switching away from carbon-intensive sources and increased effort towards energy efficiency and sustainable energy. Subsidies and support from governments to fossil fuels encourage the opposite.

Many countries and regions are making this switch: from subsidising fossil fuels and towards investing in sustainable energy. This brochure describes how Ethiopia, Morocco, Peru and the Philippines have reformed their subsidies. It also describes how countries including Denmark, Finland, Norway and Sweden have introduced innovative policy instruments to encourage switching towards renewable and sustainable energy. 